\title{
A systematic review of type 2 diabetes mellitus and hypertension in imaging studies of cognitive aging: time to establish new norms
}

\author{
Liesel-Ann C. Meusel ${ }^{1}$, Nisha Kansal' ${ }^{1}$ Ekaterina Tchistiakova ${ }^{2,3}$, William Yuen ${ }^{1,4}$, \\ Bradley J. Maclntosh ${ }^{2,3}$, Carol E. Greenwood ${ }^{1,4}$ and Nicole D. Anderson ${ }^{1,5 *}$ \\ 1 Baycrest Centre, Rotman Research Institute, Toronto, ON, Canada \\ ${ }^{2}$ Sunnybrook Research Institute, Heart and Stroke Foundation Canadian Partnership for Stroke Recovery, Toronto, ON, Canada \\ ${ }^{3}$ Department of Medical Biophysics, Faculty of Medicine, University of Toronto, Toronto, ON, Canada \\ ${ }^{4}$ Department of Nutritional Sciences, Faculty of Medicine, University of Toronto, Toronto, ON, Canada \\ ${ }^{5}$ Departments of Psychology and Psychiatry, University of Toronto, Toronto, ON, Canada
}

\section{Edited by:}

Rodrigo Orlando Kuljiš, Zdrav Mozak

Limitada, Chile

Reviewed by:

Peter Mikael Nilsson, Lund

University, Sweden, Sweden

Ibrahim F. Shatat, Medical University

of South Carolina Children's

Hospital, USA

*Correspondence:

Nicole D. Anderson, Rotman

Research Institute, Baycrest,

3560 Bathurst Street, Toronto,

ON M6A 2E1, Canada

e-mail:nanderson@

research.baycrest.org
The rising prevalence of type 2 diabetes (T2DM) and hypertension in older adults, and the deleterious effect of these conditions on cerebrovascular and brain health, is creating a growing discrepancy between the "typical" cognitive aging trajectory and a "healthy" cognitive aging trajectory. These changing health demographics make T2DM and hypertension important topics of study in their own right, and warrant attention from the perspective of cognitive aging neuroimaging research. Specifically, interpretation of individual or group differences in blood oxygenation level dependent magnetic resonance imaging (BOLD MRI) or positron emission tomography $\left(\mathrm{PET} \mathrm{H}_{2} \mathrm{O}^{15}\right.$ ) signals as reflective of differences in neural activation underlying a cognitive operation of interest requires assumptions of intact vascular health amongst the study participants. Without adequate screening, inclusion of individuals with T2DM or hypertension in "healthy" samples may introduce unwanted variability and bias to brain and/or cognitive measures, and increase potential for error. We conducted a systematic review of the cognitive aging neuroimaging literature to document the extent to which researchers account for these conditions. Of the 232 studies selected for review, few explicitly excluded individuals with T2DM $(9 \%)$ or hypertension $(13 \%)$. A large portion had exclusion criteria that made it difficult to determine whether T2DM or hypertension were excluded (44 and $37 \%$ ), and many did not mention any selection criteria related to T2DM or hypertension (34 and 22\%). Of all the surveyed studies, only $29 \%$ acknowledged or addressed the potential influence of intersubject vascular variability on the measured BOLD or PET signals. To reinforce the notion that individuals with T2DM and hypertension should not be overlooked as a potential source of bias, we also provide an overview of metabolic and vascular changes associated with T2DM and hypertension, as they relate to cerebrovascular and brain health.

Keywords: type 2 diabetes mellitus, hypertension, cognition, aging, imaging

\section{INTRODUCTION}

Amongst middle-aged and older adults, the rising prevalence of T2DM, hypertension, and other conditions that comprise the metabolic syndrome is a global health epidemic, attributed largely to sedentary lifestyles, poor diet, and lack of exercise. In 2008, it was estimated that 347 million adults worldwide had T2DM, up from 153 million in 1980 (Danaei et al., 2011). Over the next two decades, it is expected that these numbers will continue to rise, by as much as $38 \%$ by 2030 (Shaw et al., 2010). Prevalence rates of hypertension are even higher. In 2000, the global prevalence of hypertension was $26.4 \%$, affecting an estimated 972 million people worldwide. Again, these numbers are expected to increase by approximately $60 \%$ by 2025 , to a total of 1.56 billion people
(Kearney et al., 2005). Critically, hypertension is present in up to $75 \%$ of individuals with T2DM (Colosia et al., 2013). The growing number of middle-aged and older adults living with T2DM and/or hypertension makes these conditions important topics of study in their own right.

Better long-term health care and disease management allow middle-aged and older adults to live with T2DM and hypertension for many years; however, both of these conditions have long-term deleterious effects on cerebrovascular and brain health, and contribute to cognitive impairment and decline (Gorelick et al., 2011). T2DM and midlife hypertension confer a high risk for development of mild cognitive impairment (MCI) and dementia (Launer et al., 2000; Kloppenborg et al., 2008; 
Creavin et al., 2012; Crane et al., 2013; Roberts et al., 2014), and older individuals with T2DM progress to dementia at faster rates (Xu et al., 2010; Morris et al., 2014). These changing health demographics have created a discrepancy: what we define as "normal" or "typical" cognitive aging is becoming farther and farther removed from what would be considered optimal, or "healthy" cognitive aging.

This trend warrants attention from the perspective of cognitive aging research. Without adequate screening procedures in place, inclusion of individuals with T2DM and hypertension in otherwise healthy study samples may introduce unwanted variability and bias to brain and/or cognitive measures, and increase the potential for type 1 and type 2 errors. Functional neuroimaging studies may be particularly vulnerable in this regard. Blood oxygenation level dependent magnetic resonance imaging (BOLD $\mathrm{MRI}$ ) and positron emission tomography (PET $\mathrm{H}_{2} \mathrm{O}^{15}$ ) measure hemodynamic changes associated with neural activity, and thus provide an indirect measure of neural function (Logothetis et al., 2001). To interpret individual or group differences in BOLD or PET signaling as reflective of individual or group differences in neural activation underlying a cognitive operation of interest, we rely on assumptions of intact neurovascular signaling, cerebrovascular reactivity, and vascular health amongst the study participants. These assumptions may be true in young and healthy individuals, but do not hold in older adults with conditions that affect vascular health (D'Esposito et al., 2003). Even normal, agerelated changes in the integrity of the cerebrovascular system can undermine these assumptions (D'Esposito et al., 1999).

Yet, it was our impression that relatively few studies in the cognitive aging neuroimaging literature consider T2DM or hypertension during recruitment, or control for potential confounds associated with these conditions during analysis. To clarify the extent to which current research practices consider T2DM and hypertension in study design, we present the results of a systematic review of the cognitive aging neuroimaging literature, looking at study inclusion/exclusion criteria and methodology related to T2DM and hypertension. Then, to reinforce the notion that individuals with T2DM and hypertension should not be overlooked as a potential source of bias, we provide an overview of metabolic and vascular changes associated with T2DM and hypertension, as they relate to vascular health, structural brain atrophy, and functional integrity. The final section discusses best practices moving forward.

\section{SYSTEMATIC REVIEW}

This review focuses on the cognitive aging neuroimaging literature, however the issues associated with inclusion of individuals with T2DM and hypertension in study samples are by no means limited to this area of research. Any research study whose population of interest has high prevalence rates of T2DM or hypertension should be cognizant of these issues. For example, psychiatric populations have a higher incidence of metabolic disruption and T2DM that is mediated, at least partially, by the use of mood stabilizers, anticonvulsants, and antipsychotic medications (Regenold et al., 2002; Newcomer and Haupt, 2006).

It should also be noted that the purpose of this review is not to quantitatively compare the results of studies that have excluded
T2DM and/or hypertension with those that have not. This type of comparison is not feasible for numerous reasons, the primary one being that the extent to which individuals with T2DM or hypertension were present in study samples that did not screen for either condition is unknown. Rather, the aim of this review is to highlight the proportion of studies in the cognitive aging neuroimaging literature that consider T2DM and/or hypertension in their inclusion/exclusion criteria, or attempt to account for the potential bias introduced by inclusion of these individuals in their study groups.

\section{METHODS}

We searched PsychInfo, MedLine, and PubMed between 1995 and February, 2013 using the search terms ["functional magnetic resonance imaging" or "positron emission tomography"], ["geriatrics" or "aging" or "age differences"], and ["cognit*" or "neuropsych*" or "memory" or "attention"]. Across the three databases, these search terms produced 704 unique empirical studies. From these results, we excluded studies that did not include a "healthy" or "normal" older adult sample $(n=125)$, included a clinical sample other than MCI or Alzheimer disease $(\mathrm{AD}) /$ dementia (e.g., psychiatric; $n=46$ ), did not use BOLD or PET $\mathrm{H}_{2} \mathrm{O}^{15}$ imaging $(n=227)$, and did not scan during a cognitive or resting state task $(n=74$; Figure 1$)$.

\section{RESULTS}

Based on these criteria, 232 studies were selected for review. These studies are identified with an asterisk $\left(^{*}\right)$ in the reference section. Two hundred and nineteen of these used BOLD imaging, one used both BOLD and PET $\mathrm{H}_{2} \mathrm{O}^{15}$, and 12 used PET $\mathrm{H}_{2} \mathrm{O}^{15}$ only. One hundred and sixty five of these studies compared a "healthy" older group with a group of young participants, 34 studies compared a "healthy" older sample to an MCI and/or AD group (two of which also included a young adult comparison group), and the remaining 33 studies looked only at a "healthy" older sample. The majority of surveyed studies employed a memory paradigm during imaging (e.g., encoding/recognition of words, pictures, scenes, faces, autobiographical memory, spatial memory, associative memory, implicit learning). Working memory and executive processes were also well-studied (e.g., cognitive control, inhibition, decision making, mental rotation, task-switching, attention, judgment, processing speed, naming, imagery, verb generation, fluency). We also included resting-state studies in the sample.

Our primary concern was how sample selection was reported to have occurred. In particular, we were interested to learn how many studies specifically screened for T2DM and/or hypertension in their healthy older adult samples. For each of the 232 identified studies, the inclusion/exclusion criteria were examined according to the following criteria: (i) explicit exclusion of T2DM and/or hypertension, or exclusion of medical disorders/physical illnesses/systemic illnesses (implying that all medical conditions, including T2DM and hypertension, were excluded); (ii) exclusion of "significant," "major," or "severe" medical/physical/systemic disorders; or (iii) no screening criteria related to T2DM and/or hypertension provided. We also surveyed each of the 232 studies to determine how subjects were screened (e.g., self-report questionnaire, clinical assessment with a medical doctor, laboratory 


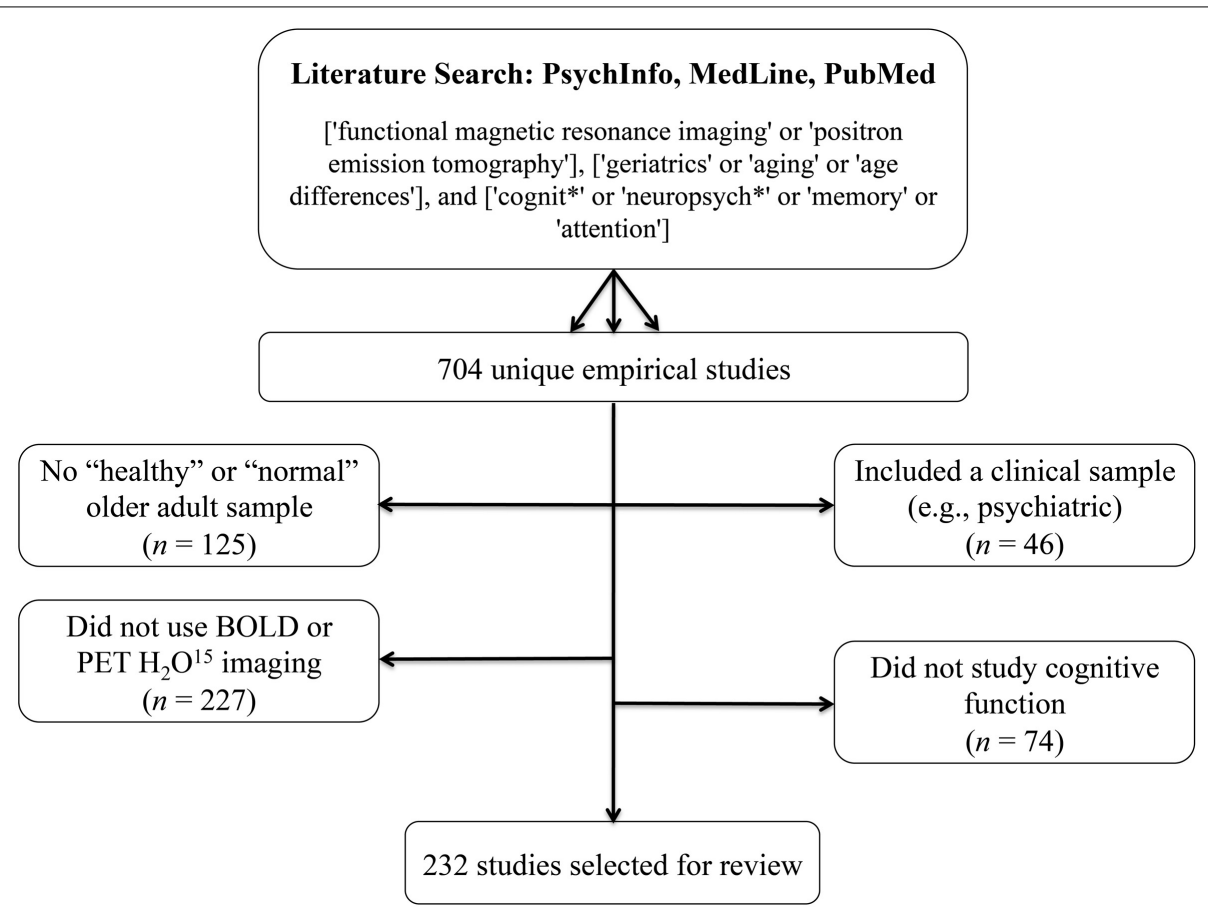

FIGURE 1 | Literature search terms and exclusion criteria. Based on these criteria, 232 studies were selected for review.

testing), and how-if at all-the potential influence of intersubject vascular variability on the measured BOLD or PET signals was addressed.

In each section below, superscript numbers, letters, and symbols are used to represent the extent to which studies screened for T2DM and hypertension, the screening method, and the degree to which studies attempted to account for intersubject vascular variability, respectively. The identified studies are denoted in the reference section according to these superscript classifiers.

\section{Inclusion/Exclusion of T2DM and hypertension}

Of the 232 studies surveyed, only 22 (9.5\%) explicitly excluded individuals with $\mathrm{T} 2 \mathrm{DM}\left({ }^{1}\right)$, and only $29(12.5 \%)$ explicitly excluded individuals with hypertension $\left({ }^{2}\right)$. Thirteen studiesapproximately $6 \%$-excluded both T2DM and hypertension. Fourteen studies $(6.0 \%)$ excluded individuals on antihypertensive medication $\left({ }^{3}\right)$, however few of these studies also clarified whether individuals were assessed for untreated hypertension and excluded, if present. Nineteen studies (8.2\%) excluded medical illnesses, systemic illnesses, medical disorders or physical illnesses $\left({ }^{4}\right)$. This criterion implies that all medical conditions, including T2DM and hypertension, were excluded.

In contrast, almost half of the included studies (102; $44.0 \%$ ) had exclusion criteria that made it difficult to determine whether T2DM was excluded $\left({ }^{5}\right)$, and 85 studies $(36.6 \%)$ had exclusion criteria that made it difficult to determine whether hypertension and/or antihypertensive medications were excluded $\left({ }^{6}\right)$. These studies listed "major medical illnesses," "significant medical conditions," "serious systemic illnesses," "conditions/medications interfering with cognitive and/or brain function," "vascular disease," “cardiovascular disease," and/or "conditions/medications interfering with the fMRI signal" as exclusion criteria, or simply described their sample as "healthy." There were also many studies that did not mention any selection criteria related to T2DM $(80 ; 34.5 \%)\left({ }^{7}\right)$ or hypertension $(51$; $22.0 \%)\left({ }^{8}\right)$.

In addition, 26 studies (11.2\%) included individuals with controlled hypertension $\left({ }^{9}\right)$, 8 studies $(3.5 \%)$ included controlled and uncontrolled hypertension $\left({ }^{10}\right)$, 3 studies $(1.3 \%)$ included individuals with controlled T2DM $\left({ }^{11}\right)$, and 6 studies $(2.5 \%)$ included individuals with controlled and uncontrolled T2DM in their healthy cohort $\left({ }^{12}\right)$. Figure 2 provides a visual depiction of these results.

\section{Screening method}

The majority of studies $(173 ; 75 \%)$ did not report how they conducted their medical screening $\left({ }^{a}\right)$. Only 28 studies $(12 \%)$ reported having screened subjects with physician-conducted medical examinations and/or laboratory testing $\left({ }^{b}\right)$. Sixteen studies $(7 \%)$ screened participants with telephone interviews, inperson clinical interviews, medical history, chart reviews, or a combination of these methods $\left({ }^{c}\right)$. The remaining 15 studies $(6 \%)$ used a self-report questionnaire to assess medical $\operatorname{status}\left({ }^{\mathrm{d}}\right)$.

\section{Accounting for intersubject vascular variability}

A survey of the 232 included studies found that just under one third (29\%) acknowledged and/or addressed the potential influence of intersubject vascular variability on the reported results. Many excluded subjects with a high vascular burden by screening 


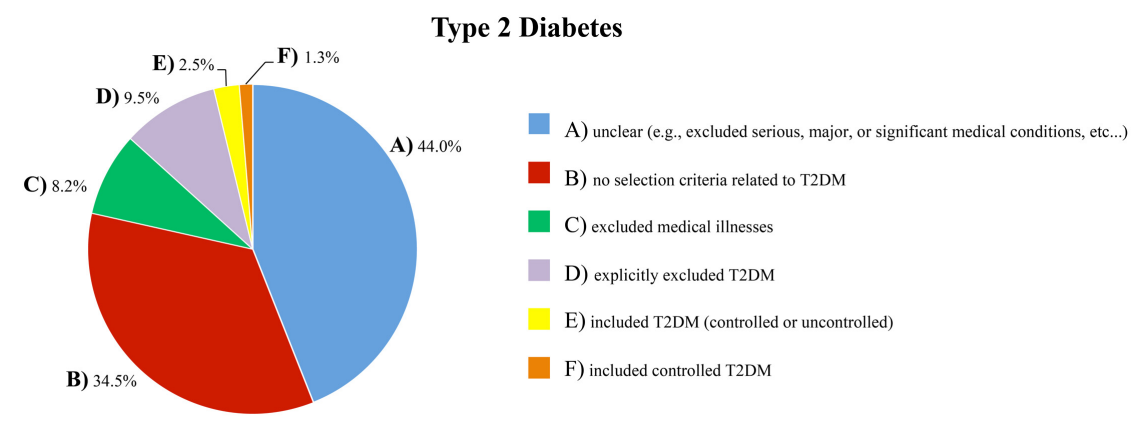

Hypertension

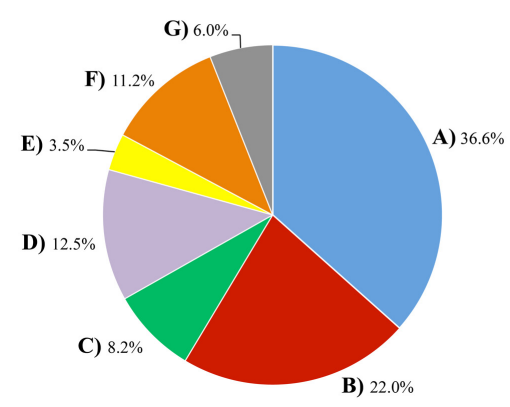

A) unclear (e.g., excluded serious, major, or significant medical conditions, etc...)
B) no selection criteria related to hypertension
C) excluded medical illnesses
D) explicitly excluded hypertension
E) included hypertension (controlled or uncontrolled)
F) included controlled hypertension
G) excluded antihypertensive medication

FIGURE 2 | The extent to which T2DM and hypertension were accounted for in the inclusion/exclusion criteria of the healthy samples that were surveyed.

for white matter hyperintensities in the imaging data $(\square)$. Others compared groups on vascular risk factors $\left({ }^{+}\right)$, compared outcome measures on hypertension status or antihypertensive treatment status $(\downarrow)$, or attempted to control for health, blood pressure, and/or white matter hyperintensities in the reported associations $\left({ }^{*}\right)$. Several studies noted in their discussion the possibility that the reported results were influenced by vascular factors, or explained why they did not think this was an issue $\left(\bullet^{\bullet}\right)$. A few studies used the measured BOLD or PET signals to examine and account for individual differences in vascular health $(\square)$; for example, by ensuring that groups were equated on BOLD signal variability, by comparing the temporal characteristics of the hemodynamic response curve across groups, with proportional scaling of the BOLD or PET signal, or by focusing on group by task interactions (instead of group main effects) or comparing within-subject task contrasts across individuals or groups to minimize any individual or group differences in vascular integrity.

There are rigorous ways to account for intersubject vascular variability, such as additional task data or an additional imaging contrast. Several studies included in the present review used arterial spin labeling (ASL) MRI $(\boldsymbol{\Delta})$ or PET $(\boldsymbol{\nabla})$ to measure resting cerebral blood flow and control for individual differences in perfusion. Three studies used a breath-hold task to index individual differences in cerebrovascular reactivity $(\mathrm{O})$, and two studies included a low-level motor or baseline task to ensure that participants demonstrated an adequate hemodynamic response $\left({ }^{\mathbf{x}}\right)$.

\section{DISCUSSION}

Our results found that fewer than $10 \%$ of the selected functional imaging studies on cognitive aging explicitly excluded individuals with T2DM from their normative samples, and fewer than $15 \%$ explicitly excluded individuals with hypertension. A number of studies reported selection criteria that were insufficient to determine whether T2DM or hypertension were screened. Critically, one third of included studies had no reported inclusion or exclusion criteria related to T2DM, while almost a quarter had no reported inclusion or exclusion criteria related to hypertension. Only 67 of the 232 selected studies (29\%) acknowledged or addressed the potential influence of intersubject vascular variability on the measured BOLD or PET signals.

Moreover, the large majority of studies did not include information about the medical screening process itself (e.g., laboratory testing vs. clinical interview vs. self-report questionnaire). This is not ideal when established tests for T2DM and hypertension are available (for example, 24-h ambulatory blood pressure monitoring would be the gold-standard for determining hypertension status, and an oral glucose tolerance test for determining T2DM status). Furthermore, we posit that participants may be less likely to volunteer T2DM or hypertension status as a "significant" medical illness without specific probing (i.e., compared to cancer, HIV, multiple sclerosis, or heart disease), because when these conditions are well-controlled they can have a minimal impact on day-to-day functioning, and, in the case of T2DM, can be controlled by diet alone. Collectively, these observations point to a lack of awareness that T2DM and hypertension are major 
medical illnesses that interfere significantly with cognitive and brain function in older adults.

\section{OVERVIEW: METABOLIC AND VASCULAR COMPLICATIONS OF TYPE 2 DIABETES MELLITUS AND HYPERTENSION}

To reinforce the position that T2DM and hypertension are conditions that can have a major effect on brain health and cognitive aging, this next section reviews evidence on the cognitive deficits, structural changes, and functional consequences associated with T2DM and hypertension, and describes some of the mechanisms that mediate these changes.

\section{TYPE 2 DIABETES MELLITUS}

T2DM is the result of peripheral insulin resistance, which leads to insulin dysregulation and hyperglycemia. These metabolic changes affect cerebrovascular health, structural integrity, and brain function, and underlie the associations between T2DM, cognitive decline, and dementia risk.

\section{Insulin dysregulation}

Insulin is a peptide hormone that is critical for regulation of blood glucose levels. Binding of insulin to its receptors, found on nearly all cells throughout the body, facilitates the cellular uptake of glucose from the blood. When bound, insulin and insulinlike growth factor also activate complex intracellular signaling pathways that promote cell growth and survival, regulate glucose metabolism, and inhibit oxidative stress and apoptosis (for a review, see Nakae et al., 2001).

The defining characteristic of T2DM is peripheral insulin resistance, which occurs when cells in the body decrease their response to insulin stimulation. In the developing stage of this disease, the pancreas is able to produce enough insulin to overcome this resistance. This results in peripheral hyperinsulinemia, and blood glucose levels remain within the normal range. As the disease progresses, however, the pancreas can no longer keep up, and blood glucose levels begin to rise. When blood glucose levels are high even in the fasting state, T2DM is diagnosed.

Peripheral insulin resistance and hyperinsulinemia have a counterintuitive impact on insulin levels within the central nervous system. In the face of peripheral hyperinsulinemia, insulin transport across the blood brain barrier is effectively reduced, resulting in a brain hypo-insulinemic state (e.g., Heni et al., 2013). Low brain insulin levels and disrupted insulin signaling contribute to cognitive impairments directly, particularly in medial temporal lobe regions where insulin receptors are abundant (Convit, 2005; Craft, 2006). Indirectly, low brain insulin levels exacerbate amyloid beta $(\mathrm{A} \beta)$ and tau pathology, hallmarks of Alzheimer disease (AD). It is here that we see the link between T2DM and Alzheimer disease pathology: brain insulin deficiency results in the down-regulation of insulin degrading enzyme (IDE; Luchsinger, 2008), which also has a role in degrading $A \beta$ (Carlsson, 2010). As a result, $A \beta$ degradation is effectively reduced, contributing to its aggregation and amyloid plaque formation. Decreased brain insulin levels also suppress the enzymes involved in tau phosphorylation, contributing to the formation of neurofibrillary tangles (Akter et al., 2011). While the downstream impact of T2DM-mediated brain insulin deficiency and insulin resistance is more moderate than that associated with $\mathrm{AD}$, the underlying pathogenic mechanisms are similar (Steen et al., 2005), and it has been proposed that AD is a form of diabetes mellitus that selectively affects the brain (T3DM; for discussion, see de la Monte and Wands, 2008). Given this, is not surprising that individuals with T2DM show a pattern of memory impairment, medial temporal lobe atrophy, and reduced hippocampal connectivity that is similar to the classic pattern of memory deficits, neurodegeneration, and network disruption in $\mathrm{AD}$ (e.g., Gold et al., 2007; Zhou et al., 2010; Baker et al., 2011; Cui et al., 2014).

\section{Hyperglycemia}

When cells in the body become resistant to the effects of insulin, blood glucose levels rise, resulting in hyperglycemia. Endothelial cells are particularly vulnerable to the effects of hyperglycemia, because they are less efficient at reducing glucose uptake in the face of high blood glucose levels (Kaiser et al., 1993). Under such conditions, the resultant intracellular hyperglycemia induces an overproduction of reactive oxygen species in the mitochondria, which increases oxidative stress within the cell. This initiates a cascade of biochemical events that mediate much of the microvascular and macrovascular damage associated with T2DM including, but not limited to, increased intracellular formation of advanced glycation end-products (AGEs) and protein kinase $\mathrm{C}$ activation (Du et al., 2000; Nishikawa et al., 2000; Brownlee, 2005; Giacco and Brownlee, 2010; Johnson, 2012).

AGEs are formed during normal metabolism on proteins with slower rates of turnover, in almost all cells throughout the body. AGE accumulation over time is a major factor in normal aging; however, under hyperglycemic conditions, AGE production is exacerbated beyond normal levels. AGEs cause intracellular damage and induce apoptosis through a process called cross-linking (Shaikh and Nicholson, 2008). AGEs also contribute to oxidative stress, and themselves activate inflammatory signaling cascades (for a review, see Yan et al., 2008). Critically, under hyperglycemic conditions, the $A \beta$ protein itself can act as an AGE (Granic et al., 2009), which enhances its own aggregation and further increases amyloid plaque formation.

Protein kinase $\mathrm{C}$ activation, on the other hand, affects a variety of changes in gene expression that culminate in vascular dysfunction. Production of nitric oxide (NO), a vasodilator, is decreased, and production of endothelin-1, a vasoconstrictor, is increased. As a result, blood vessels are less able to dilate to accommodate increased blood flow demand. Over time, chronic exposure to high concentrations of endothelin-1 and decreased concentrations of NO contribute to diminished vessel elasticity, and structural changes in the vessel wall that result in atherosclerotic plaque formation (Kalani, 2008).

In the brain, hyperglycemia-mediated macro- and microvascular damage reduces the delivery of nutrients and oxygen required to meet metabolic demands. Altered cerebral autoregulation has been observed in middle-aged adults with T2DM (Brown et al., 2008), and may be an early manifestation of microvascular disease (Kim et al., 2008). Older adults with T2DM show decreased blood flow velocity, increased cerebrovascular resistance, and impaired vasoreactivity (Novak et al., 2006). Over time, declines in cerebrovascular health and reduced perfusion 
of brain tissue lead to structural atrophy and altered brain function.

\section{Cognitive effects}

The cognitive profile of individuals with T2DM includes deficits in attention, processing speed, learning and memory, and executive function (e.g., Reaven et al., 1990; Brands et al., 2007; Yeung et al., 2009; Whitehead et al., 2011). Moreover, these individuals, and individuals with pre-diabetes (impaired glucose tolerance), show an accelerated trajectory of cognitive decline relative to that associated with healthy aging (Gregg et al., 2000; Fontbonne et al., 2001; Arvanitakis et al., 2004; Yaffe et al., 2004; Fischer et al., 2009; Nooyens et al., 2010; Espeland et al., 2011; for conflicting results, see van den Berg et al., 2010).

Cognitive deficits in T2DM have been linked to multiple disease-related processes, including: (i) poor glucose control (i.e., hemoglobin A1c [HbAlc]; Ryan and Geckle, 2000; Kanaya et al., 2004; Cukierman-Yaffe et al., 2009; Maggi et al., 2009; Luchsinger et al., 2011; Tuligenga et al., 2014; for conflicting results, see Christman et al., 2011), (ii) glucose intolerance (Rizzo et al., 2010; Zhong et al., 2012b), (iii) high peripheral AGE levels (Yaffe et al., 2011), (iv) high levels of inflammatory cytokines (Marioni et al., 2010), and (v) peripheral hyperinsulinemia and insulin resistance (Bruehl et al., 2010; Zhong et al., 2012a). Even in nondiabetic adults, poorer glucoregulation has been associated with deficits and/or declines in verbal memory, working memory, processing speed, and executive function (Dahle et al., 2009; Bruehl et al., 2010; Messier et al., 2010, 2011; Ravona-Springer et al., 2012).

The link between cognitive impairment and poor metabolic control may be largely mediated by the structural and functional brain changes that occur in the presence of chronic insulin dysregulation and hyperglycemia. Associations between glucoregulation, hypoperfusion in temporal regions, hippocampal atrophy, and memory impairment have been observed in T2DM (Gold et al., 2007; Last et al., 2007), and in non-diabetic adults with decreased peripheral glucose regulation (Convit et al., 2003), or high fasting plasma glucose levels within the normal range (Cherbuin et al., 2012; Kerti et al., 2013). In other studies of T2DM, cognitive deficits and structural brain atrophy were linked to cerebral hypoperfusion and altered vascular reactivity (Last et al., 2007; Brundel et al., 2012), and disrupted default-mode network connectivity was associated with peripheral hyperinsulinemia, insulin resistance, and white matter integrity (Musen et al., 2012; Hoogenboom et al., 2014). Regardless of the underlying cause, brain atrophy in T2DM is associated with poor cognition (Moran et al., 2013), and cognitive declines have been associated with progression of brain atrophy over time (van Elderen et al., 2010; Reijmer et al., 2011). Some studies suggest that structural changes may occur early in the course of T2DM; enlarged lateral ventricles, particularly within the frontal horns, have been observed less than a year after diagnosis (Lee et al., 2013), and middle-aged, as well as older adults with T2DM, show reduced prefrontal volumes (Bruehl et al., 2009) and generalized global atrophy (de Bresser et al., 2010; Kamiyama et al., 2010; Espeland et al., 2013).

\section{HYPERTENSION}

The brain is one of the most highly perfused organs. The cerebral hemispheres are supplied by capillary beds connected to the pial vasculature by penetrating arterioles, and the pial vasculature stems from a system of arteries branching off the anterior, middle, and posterior cerebral arteries. Maintenance of brain function depends on a constant blood supply through this network. Hypertension causes changes to the structure and function of these blood vessels, which impacts perfusion in affected areas. Hypoperfusion, for example, can interfere with the delivery of oxygen and nutrients required to meet metabolic demands, and makes hypertension a major risk factor for vascular cognitive impairment, stroke, and dementia.

\section{Cerebrovascular changes}

Hypertension places enormous stress on the cerebral circulation (for a comprehensive review, see Pires et al., 2013). A hallmark of chronic hypertension is increased vascular resistance, particularly in the small blood vessels that perfuse the brain. Vascular resistance increases as vessel walls thicken. This remodeling is an adaptive response required to maintain chronically increased blood pressure, but it decreases the interior space of the blood vessels (the lumen). Vascular resistance also increases as the number of blood vessels decrease. Rat models of hypertension have shown both of these effects: reductions in lumen diameter and in the number of capillaries making up capillary beds in the cerebral vasculature (Sokolova et al., 1985).

Blood flow is reduced when vascular resistance is high, and chronic hypertension-mediated hypoperfusion has been linked to white matter degradation, gray matter atrophy, and cognitive deficits. Studies of older adults with hypertension show reduced blood flow, particularly in occipito-temporal, prefrontal, and medial temporal lobe regions (Beason-Held et al., 2007), positive correlations between blood pressure and white matter burden (White et al., 2011; Raji et al., 2012), and negative correlations between blood pressure and total brain volume (Nagai et al., 2008). Blood vessel function is also impacted by hypertension. Cerebral autoregulation (i.e., the ability to maintain a constant perfusion rate over a range of arterial pressures) is impaired, as is cerebrovascular reactivity, the ability of blood vessels to dilate to accommodate increased blood flow demand (Last et al., 2007; Hajjar et al., 2010).

\section{Cognitive effects}

The cognitive profile of older adults with hypertension includes poorer performance on tests of executive function, including verbal fluency, Trails B-A switching score, Stroop interference scores (Bucur and Madden, 2010), slowed processing speed (Dahle et al., 2009), and deficits in attention and memory (see Gifford et al., 2013 for a meta-analysis). Prospective cohort studies show that midlife cardiovascular risk factors like hypertension predict cognitive impairment in later life (e.g., Virta et al., 2013), and, similarly, cross-sectional studies show a relation between higher systolic blood pressure and poorer cognitive performance, even within the normotensive range, a relation that is particularly strong in midlife (e.g., Knecht et al., 2008, 2009). Hypertension is associated with decreases in cognitive reserve (Giordano et al., 
2012), and older adults with MCI and cardiovascular risk factors like hypertension are twice as likely to develop dementia compared to those without such risk factors (Johnson et al., 2010; Ettorre et al., 2012). Moreover, cognitive declines may be faster in those with MCI and hypertension, compared to those without hypertension (Li et al., 2011; Goldstein et al., 2013).

The association between hypertension and cognitive decline appears to be strongest in executive and processing speed domains, and weakest in memory and language domains. Hypertension increased the risk of non-amnestic MCI, but not amnestic MCI, regardless of APOE 4 genotype or hypertensive medication status (Reitz et al., 2007), and predicted progression to dementia in non-amnestic MCI, but not amnestic or multidomain MCI (Oveisgharan and Hachinski, 2010). The impact of hypertension on executive and processing speed domains is consistent with studies that show a positive relation between hypertension and white matter changes (Kennedy and Raz, 2009; Raz et al., 2012), and between white matter changes and deficits in processing speed, executive function, and attention, but not memory (e.g., Debette et al., 2011).

Cognitive deficits in hypertensive adults are linked to various indicators of vascular and brain health. There are correlations between white matter integrity and performance on tests of executive function and attention (Hannesdottir et al., 2009), and between decreased flow-mediated dilation and poorer executive function (Smith et al., 2011). Deficits in attention and psychomotor speed in late middle-aged adults with hypertension are associated with reductions in global brain perfusion, reductions that were not fully ameliorated following 6-months of antihypertensive treatment (Efimova et al., 2008). Global cognitive decline has been linked to reduced cerebral blood flow in the face of white matter lesions and lacunar infarcts (Kitagawa et al., 2009), to higher pulse pressure and arterial stiffness (Scuteri et al., 2007; Waldstein et al., 2008; Triantafyllidi et al., 2009), and to hypertension-mediated deep-brain vascular pathology (Yakushiji et al., 2012). In another large study of patients with MCI, those with hypertension and deep white matter lesions were at higher risk of dementia (Clerici et al., 2012).

\section{CONCLUSIONS}

Taken together, these studies provide abundant evidence that middle-aged and older adults with T2DM and hypertension, relative to healthy older adults, are more likely to show signs of cognitive dysfunction, widespread structural atrophy, vascular damage, and functional changes. In light of their rising prevalence amongst older adults, there is an increasing likelihood that, without adequate screening at recruitment, individuals with T2DM and/or hypertension will be included in healthy older adult samples. This may introduce unwanted variability and bias to brain and/or cognitive measures, and increase the potential for type 1 and type 2 errors. Given the state of the neuroimaging literature on this topic and the need to advance our understanding, we view T2DM and hypertension as important new frontiers in cognitive neuroscience.

Moving forward, there is an opportunity to develop best practices when it comes to cognitive neuroscience research in older adult populations. Reconciling the vascular risk component in
T2DM and hypertension may be the most tractable option since there are myriad approaches one can take to do this. The most rigorous approach in this respect may be inclusion of a breath-hold task, or a measure of cerebral blood flow (e.g., ASL) in the functional imaging protocol, as this allows for a direct estimate of each subject's vascular health. Breath-hold tasks can be used to index cerebrovascular reactivity in response to non-neuronal signals. The breath-hold period induces hypercapnia, which stimulates vasodilation and increases blood flow and blood volume in the brain, a signal change that occurs independently of neuronal activation. ASL or resting-state PET scans provide a direct measure of blood flow, and can be used to account for individual differences in perfusion. As noted above, these methods have already been used in some studies of cognitive aging to account for individual differences in cerebrovascular health. Whether other means of equating vascular risk across participants or across groups (e.g., screening participants for excessive white matter hyperintensities, post-hoc comparison of outcome measures or study groups on vascular risk factors, or statistical analyses aimed at controlling for the effects of vascular variability in the reported results) are similarly effective requires further study.

It may also be important for investigators to acknowledge a distinction between "healthy" and "typical" brain aging. Studies characterizing healthy aging should adopt T2DM and hypertension as exclusion criteria. Conversely, given the high prevalence of T2DM and hypertension in older adults, community- or population-based studies characterizing the typical trajectory of cognitive aging would benefit by including these participants to maximize the generalizability of results, and reconciling the heterogeneity through study design groups (e.g., stratifying based on diagnosis of T2DM and hypertension) or covariates in their analysis.

As the proportion of older adults living with T2DM and hypertension increase, it is imperative that functional imaging studies are designed to account for these population trends. The current state of the cognitive aging neuroimaging literature suggests that there is limited appreciation and/or awareness that T2DM and hypertension are significant medical illnesses that disrupt brain vasculature, brain structure, and brain function. By adopting best practices that take T2DM and hypertension into account, we can advance our understanding of these conditions, and of cognitive aging in general.

\section{AUTHOR CONTRIBUTIONS}

Liesel-Ann C. Meusel selecting, indexing, and reviewing articles, writing of drafts; Nisha Kansal selecting articles, editing of drafts; Ekaterina Tchistiakova contributing to the first draft, editing of drafts; William Yuen selecting articles, contributing to the first draft, editing of drafts; Bradley J. MacIntosh provided conceptual foundation for paper, editing of drafts; Carol E. Greenwood provided conceptual foundation for paper, editing of drafts; Nicole D. Anderson provided conceptual foundation for paper, editing of drafts.

\section{ACKNOWLEDGMENTS}

This research was supported in part by postdoctoral fellowships from the Centre for Stroke Recovery and the Alzheimer Society of 
Canada awarded to Liesel-Ann C. Meusel, and grant funds from CIHR (MOP111244).

\section{REFERENCES}

Akter, K., Lanza, E. A., Martin, S. A., Myronyuk, N., Rua, M., and Raffa, R. B. (2011). Diabetes mellitus and Alzheimer's disease: shared pathology and treatment? Br. J. Clin. Pharmacol. 71, 365-376. doi: 10.1111/j.13652125.2010.03830.x

*5,6,a Anderson, K. E., Lynch, K., Zarahn, E., Scarmeas, N., Van Heertum, R., Sackeim, H., et al. (2005). H215O PET study of impairment of nonverbal recognition with normal aging. J. Neuropsychiatry Clin. Neurosci. 17, 192-200. doi: 10.1176/appi.neuropsych.17.2.192

${ }^{* 7,8, d}$ Anguera, J. A., Reuter-Lorenz, P. A., Willingham, D. T., and Seidler, R. D. (2011). Failure to engage spatial working memory contributes to agerelated declines in visuomotor learning. J. Cogn. Neurosci. 23, 11-25. doi: 10.1162/jocn.2010.21451

*5,6,a Ansado, J., Monchi, O., Ennabil, N., Faure, S., and Joanette, Y. (2012). Loaddependent posterior-anterior shift in aging in complex visual selective attention situations. Brain Res. 1454, 14-22. doi: 10.1016/j.brainres.2012.02.061

$* 5,6, a, \square$ Antonova, E., Parslow, D., Brammer, M., Dawson, G. R., Jackson, S. H. D., and Morris, R. G. (2009). Age-related neural activity during allocentric spatial memory. Memory 17, 125-143. doi: 10.1080/09658210802077348

Arvanitakis, Z., Wilson, R. S., Bienias, J. L., Evans, D. A., and Bennett, D. A. (2004). Diabetes mellitus and risk of Alzheimer disease and decline in cognitive function. Arch. Neurol. 61, 661-666. doi: 10.1001/archneur.61.5.661

*5,6,b Bäckman, L., Karlsson, S., Fischer, H., Karlsson, P., Brehmer, Y., Rieckmann, A., et al. (2011). Dopamine $\mathrm{D}(1)$ receptors and age differences in brain activation during working memory. Neurobiol. Aging 32, 1849-1856. doi: 10.1016/j.neurobiolaging.2009.10.018

${ }^{* 5,6, a}$ Bagurdes, L. A., Mesulam, M. M., Gitelman, D. R., Weintraub, S., and Small, D. M. (2008). Modulation of the spatial attention network by incentives in healthy aging and mild cognitive impairment. Neuropsychologia 46, 2943-2948. doi: 10.1016/j.neuropsychologia.2008.06.005

${ }^{* 5,6, c}$ Bai, F., Liao, W., Watson, D. R., Shi, Y., Wang, Y., Yue, C., et al. (2011). Abnormal whole-brain functional connection in amnestic mild cognitive impairment patients. Behav. Brain Res. 216, 666-672. doi: 10.1016/j.bbr.2010. 09.010

${ }^{* 5,6, a}$ Bai, F., Zhang, Z., Yu, H., Shi, Y., Yuan, Y., Zhu, W., et al. (2008). Default-mode network activity distinguishes amnestic type mild cognitive impairment from healthy aging: a combined structural and resting-state functional MRI study. Neurosci. Lett. 438, 111-115. doi: 10.1016/j.neulet.2008.04.021

Baker, L. D., Cross, D. J., Minoshima, S., Belongia, D., Watson, G. S., and Craft, S. (2011). Insulin resistance and Alzheimer-like reductions in regional cerebral glucose metabolism for cognitively normal adults with prediabetes or early type 2 diabetes. Arch. Neurol. 68, 51-57. doi: 10.1001/archneurol.2010.225

*5,6,c, Bangen, K. J., Kaup, A. R., Mirzakhanian, H., Wierenga, C. E., Jeste, D. V., and Eyler, L. T. (2012). Compensatory brain activity during encoding among older adults with better recognition memory for face-name pairs: an integrative functional, structural, and perfusion imaging study. J. Int. Neuropsychol. Soc. 18, 402-413. doi: 10.1017/S1355617712000197

$* 9,12, b, \wedge$ Bangen, K. J., Restom, K., Liu, T. T., Jak, A. J., Wierenga, C. E., Salmon, D. P., et al. (2009). Differential age effects on cerebral blood flow and BOLD response to encoding: associations with cognition and stroke risk. Neurobiol. Aging 30, 1276-1287. doi: 10.1016/j.neurobiolaging.2007.11.012

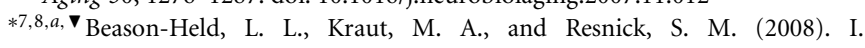
Longitudinal changes in aging brain function. Neurobiol. Aging 29, 483-496. doi: 10.1016/j.neurobiolaging.2006.10.031

Beason-Held, L. L., Moghekar, A., Zonderman, A. B., Kraut, M. A., and Resnick, S. M. (2007). Longitudinal changes in cerebral blood flow in the older hypertensive brain. Stroke 38, 1766-1773. doi: 10.1161/STROKEAHA.106.477109

${ }^{* 9,12, c,+}$ Beeri, M. S., Lee, H., Cheng, H., Wollman, D., Silverman, J. M., and Prohovnik, I. (2011). Memory activation in healthy nonagenarians. Neurobiol. Aging 32, 515-523. doi: 10.1016/j.neurobiolaging.2009.02.022

$* 1,2, a$ Berlingeri, M., Bottini, G., Danelli, L., Ferri, F., Traficante, D., Sacheli, L., et al. (2010). With time on our side? Task-dependent compensatory processes in graceful aging. Exp. Brain Res. 205, 307-324. doi: 10.1007/s00221-010-2363-7

${ }^{* 4, a}$ Bernard, F. A., Desgranges, B., Eustache, F., and Baron, J.-C. (2007). Neural correlates of age-related verbal episodic memory decline: a PET study with combined subtraction/correlation analysis. Neurobiol. Aging 28, 1568-1576. doi: 10.1016/j.neurobiolaging.2006.07.004

*5,6,a Bollinger, J., Rubens, M. T., Masangkay, E., Kalkstein, J., and Gazzaley, A. (2011). An expectation-based memory deficit in aging. Neuropsychologia 49, 1466-1475. doi: 10.1016/j.neuropsychologia.2010.12.021

Brands, A. M. A., Van den Berg, E., Manschot, S. M., Biessels, G. J., Kappelle, L. J., De Haan, E. H. F., et al. (2007). A detailed profile of cognitive dysfunction and its relation to psychological distress in patients with type 2 diabetes mellitus. J. Int. Neuropsychol. Soc. 13, 288-297. doi: 10.1017/S1355617707070312

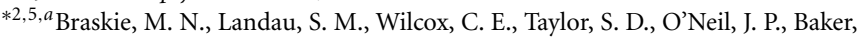
S. L., et al. (2011). Correlations of striatal dopamine synthesis with default network deactivations during working memory in younger adults. Hum. Brain Mapp. 32, 947-961. doi: 10.1002/hbm.21081

${ }^{* 5,6, a}$ Braskie, M. N., Small, G. W., and Bookheimer, S. Y. (2009). Entorhinal cortex structure and functional MRI response during an associative verbal memory task. Hum. Brain Mapp. 30, 3981-3992. doi: 10.1002/hbm.20823

$* 1,10, b, *$ Braskie, M. N., Small, G. W., and Bookheimer, S. Y. (2010). Vascular health risks and fMRI activation during a memory task in older adults. Neurobiol. Aging 31, 1532-1542. doi: 10.1016/j.neurobiolaging.2008.08.016

Brown, C. M., Marthol, H., Zikeli, U., Ziegler, D., and Hilz, M. J. (2008). A simple deep breathing test reveals altered cerebral autoregulation in type 2 diabetic patients. Diabetologia 51, 756-761. doi: 10.1007/s00125-008-0958-3

Brownlee, M. (2005). The pathobiology of diabetic complications: a unifying mechanism. Diabetes 54, 1615-1625. doi: 10.2337/diabetes.54.6.1615

Bruehl, H., Sweat, V., Hassenstab, J., Polyakov, V., and Convit, A. (2010). Cognitive impairment in nondiabetic middle-aged and older adults is associated with insulin resistance. J. Clin. Exp. Neuropsychol. 32, 487-493. doi: $10.1080 / 13803390903224928$

Bruehl, H., Wolf, O. T., Sweat, V., Tirsi, A., Richardson, S., and Convit, A. (2009). Modifiers of cognitive function and brain structure in middle-aged and elderly individuals with type 2 diabetes mellitus. Brain Res. 1280, 186-194. doi: 10.1016/j.brainres.2009.05.032

Brundel, M., van den Berg, E., Reijmer, Y. D., de Bresser, J., Kappelle, L. J., and Biessels, G. J. (2012). Cerebral haemodynamics, cognition and brain volumes in patients with type 2 diabetes. J. Diabetes Complicat. 26, 205-209. doi: 10.1016/j.jdiacomp.2012.03.021

Bucur, B., and Madden, D. J. (2010). Effects of adult age and blood pressure on executive function and speed of processing. Exp. Aging Res. 36, 153-168. doi: $10.1080 / 03610731003613482$

*7,9,a Burgmans, S., van Boxtel, M. P. J., Vuurman, E. F. P. M., Evers, E. A. T., and Jolles, J. (2010). Increased neural activation during picture encoding and retrieval in 60-year-olds compared to 20-year-olds. Neuropsychologia 48, 2188-2197. doi: 10.1016/j.neuropsychologia.2010.04.011

*2,5, ${ }^{a}$ Cabeza, R., Anderson, N. D., Locantore, J. K., and McIntosh, A. R. (2002). Aging gracefully: compensatory brain activity in high-performing older adults. Neuroimage 17, 1394-1402. doi: 10.1006/nimg.2002.1280

${ }^{* 2,5, d}$ Cabeza, R., Daselaar, S. M., Dolcos, F., Prince, S. E., Budde, M., and Nyberg, L. (2004). Task-independent and task-specific age effects on brain activity during working memory, visual attention and episodic retrieval. Cereb. Cortex 14, 364-375. doi: 10.1093/cercor/bhg133

${ }^{* 2,5, a}$ Cabeza, R., Grady, C. L., Nyberg, L., McIntosh, A. R., Tulving, E., Kapur, S., et al. (1997). Age-related differences in neural activity during memory encoding and retrieval: a positron emission tomography study. J. Neurosci. 17, 391-400.

${ }^{* 7,8, a}$ Campbell, K. L., Grady, C. L., Ng, C., and Hasher, L. (2012). Age differences in the frontoparietal cognitive control network: implications for distractibility. Neuropsychologia 50, 2212-2223. doi: 10.1016/j.neuropsychologia.2012.05.025

${ }^{* 7,8, a}$ Cappell, K. A., Gmeindl, L., and Reuter-Lorenz, P. A. (2010). Age differences in prefontal recruitment during verbal working memory maintenance depend on memory load. Cortex 46, 462-473. doi: 10.1016/j.cortex.2009.11.009

${ }^{* 7,8, a}$ Carlson, M. C., Erickson, K. I., Kramer, A. F., Voss, M. W., Bolea, N., Mielke, M., et al. (2009). Evidence for neurocognitive plasticity in at-risk older adults: the experience corps program. J. Gerontol. A Biol. Sci. Med. Sci. 64, 1275-1282. doi: $10.1093 /$ gerona/glp117

Carlsson, C. M. (2010). Type 2 diabetes mellitus, dyslipidemia, and Alzheimer's disease. J. Alzheimers. Dis. 20, 711-722. doi: 10.3233/JAD-2010-100012

${ }^{* 7,8, a}$ Celone, K. A., Calhoun, V. D., Dickerson, B. C., Atri, A., Chua, E. F., Miller, S. L., et al. (2006). Alterations in memory networks in mild cognitive impairment and Alzheimer's disease: an independent component analysis. J. Neurosci. 26, 10222-10231. doi: 10.1523/JNEUROSCI.2250-06.2006 
${ }^{* 2,5, a}$ Chen, N., Chou, Y., Song, A. W., and Madden, D. J. (2009). Measurement of spontaneous signal fluctuations in fMRI: adult age differences in intrinsic functional connectivity. Brain Struct. Funct. 213, 571-585. doi: 10.1007/s00429009-0218-4

Cherbuin, N., Sachdev, P., and Anstey, K. J. (2012). Higher normal fasting plasma glucose is associated with hippocampal atrophy: the PATH Study. Neurology 79, 1019-1026. doi: 10.1212/WNL.0b013e31826846de

Christman, A. L., Matsushita, K., Gottesman, R. F., Mosley, T., Alonso, A., Coresh, J., et al. (2011). Glycated haemoglobin and cognitive decline: the Atherosclerosis Risk in Communities (ARIC) study. Diabetologia 54, 1645-1652. doi: 10.1007/s00125-011-2095-7

${ }^{* 5,6, a}$ Chua, E. F., Schacter, D. L., and Sperling, R. A. (2009). Neural basis for recognition confidence in younger and older adults. Psychol. Aging 24, 139-153. doi: $10.1037 / \mathrm{a} 0014029$

$* 5,6, b$ Clément, F., and Belleville, S. (2009). Test-retest reliability of fMRI verbal episodic memory paradigms in healthy older adults and in persons with mild cognitive impairment. Hum. Brain Mapp. 30, 4033-4047. doi: 10.1002/hbm.20827

Clerici, F., Caracciolo, B., Cova, I., Fusari Imperatori, S., Maggiore, L., Galimberti, D., et al. (2012). Does vascular burden contribute to the progression of mild cognitive impairment to dementia? Dement. Geriatr. Cogn. Disord. 34, 235-243. doi: $10.1159 / 000343776$

Colosia, A. D., Palencia, R., and Khan, S. (2013). Prevalence of hypertension and obesity in patients with type 2 diabetes mellitus in observational studies: a systematic literature review. Diabetes Metab. Syndr. Obes. 6, 327-338. doi: 10.2147/DMSO.S51325

Convit, A. (2005). Links between cognitive impairment in insulin resistance: an explanatory model. Neurobiol. Aging 26(Suppl. 1), 31-35. doi: 10.1016/j.neurobiolaging.2005.09.018

Convit, A., Wolf, O. T., Tarshish, C., and de Leon, M. J. (2003). Reduced glucose tolerance is associated with poor memory performance and hippocampal atrophy among normal elderly. Proc. Natl. Acad. Sci. U.S.A. 100, 2019-2022. doi: 10.1073/pnas.0336073100

${ }^{* 7,8, b}$ Cook, I. A., Bookheimer, S. Y., Mickes, L., Leuchter, A. F., and Kumar, A. (2007). Aging and brain activation with working memory tasks: an fMRI study of connectivity. Int. J. Geriatr. Psychiatry 22, 332-342. doi: 10.1002/gps.1678

Craft, S. (2006). Insulin resistance syndrome and Alzheimer disease: pathophysiologic mechanisms and therapeutic implications. Alzheimer Dis. Assoc. Disord. 20, 298-301. doi: 10.1097/01.wad.0000213866.86934.7e

Crane, P. K., Walker, R., Hubbard, R. A., Li, G., Nathan, D. M., Zheng, H., et al. (2013). Glucose levels and risk of dementia. N. Engl. J. Med. 369, 540-548. doi: 10.1056/NEJMoa1215740

Creavin, S. T., Gallacher, J., Bayer, A., Fish, M., Ebrahim, S., and Ben-Shlomo, Y. (2012). Metabolic syndrome, diabetes, poor cognition, and dementia in the Caerphilly prospective study. J. Alzheimers Dis. 28, 931-939. doi: 10.3233/JAD2011-111550

Cui, Y., Jiao, Y., Chen, Y.-C., Wang, K., Gao, B., Wen, S., et al. (2014). Altered spontaneous brain activity in type 2 diabetes: a resting-state functional MRI study. Diabetes 63, 749-760. doi: 10.2337/db13-0519

Cukierman-Yaffe, T., Gerstein, H. C., Williamson, J. D., Lazar, R. M., Lovato, L., Miller, M. E., et al. (2009). Relationship between baseline glycemic control and cognitive function in individuals with type 2 diabetes and other cardiovascular risk factors: the action to control cardiovascular risk in diabetesmemory in diabetes (ACCORD-MIND) trial. Diabetes Care 32, 221-226. doi: $10.2337 / \mathrm{dc} 08-1153$

Dahle, C. L., Jacobs, B. S., and Raz, N. (2009). Aging, vascular risk, and cognition: blood glucose, pulse pressure, and cognitive performance in healthy adults. Psychol. Aging 24, 154-162. doi: 10.1037/a0014283

Danaei, G., Finucane, M. M., Lu, Y., Singh, G. M., Cowan, M. J., Paciorek, C. J., et al. (2011). National, regional, and global trends in fasting plasma glucose and diabetes prevalence since 1980: systematic analysis of health examination surveys and epidemiological studies with 370 country-years and 2.7 million participants. Lancet 378, 31-40. doi: 10.1016/S0140-6736(11)60679-X

*2,5,d Daselaar, S. M., Fleck, M. S., Dobbins, I. G., Madden, D. J., and Cabeza, R. (2006). Effects of healthy aging on hippocampal and rhinal memory functions: an event-related fMRI study. Cereb. Cortex 16, 1771-1782. doi: 10.1093/cercor/bhj112

${ }^{* 7,8, d}$ Daselaar, S. M., Veltman, D. J., Rombouts, S. A. R. B., Raaijmakers, J. G. W., and Jonker, C. (2003). Neuroanatomical correlates of episodic encoding and retrieval in young and elderly subjects. Brain 126, 43-56. doi: 10.1093/brain/awg005

${ }^{* 2,5, a}$ Davis, S. W., Dennis, N. A., Daselaar, S. M., Fleck, M. S., and Cabeza, R. (2008). Que PASA? The posterior-anterior shift in aging. Cereb. Cortex 18, 1201-1209. doi: 10.1093/cercor/bhm155

Debette, S., Seshadri, S., Beiser, A., Au, R., Himali, J. J., Palumbo, C., et al. (2011). Midlife vascular risk factor exposure accelerates structural brain aging and cognitive decline. Neurology 77, 461-468. doi: 10.1212/WNL.0b013e318227b227

de Bresser, J., Tiehuis, A. M., van den Berg, E., Reijmer, Y. D., Jongen, C., Kappelle, L. J., et al. (2010). Progression of cerebral atrophy and white matter hyperintensities in patients with type 2 diabetes. Diabetes Care 33, 1309-1314. doi: $10.2337 / \mathrm{dc09}-1923$

${ }^{* 7,9, a}$ de Chastelaine, M., Wang, T. H., Minton, B., Muftuler, L. T., and Rugg, M. D. (2011). The effects of age, memory performance, and callosal integrity on the neural correlates of successful associative encoding. Cereb. Cortex 21, 2166-2176. doi: 10.1093/cercor/bhq294

de la Monte, S. M., and Wands, J. R. (2008). Alzheimer's disease is type 3 diabetes-evidence reviewed. J. Diabetes Sci. Technol. 2, 1101-1113. doi: $10.1177 / 193229680800200619$

${ }^{* 5,6, a}$ Dennis, N. A., and Cabeza, R. (2011). Age-related dedifferentiation of learning systems: an fMRI study of implicit and explicit learning. Neurobiol. Aging 32, 2318.e17-30. doi: 10.1016/j.neurobiolaging.2010.04.004

*5,6,a Dennis, N. A., Daselaar, S., and Cabeza, R. (2007a). Effects of aging on transient and sustained successful memory encoding activity. Neurobiol. Aging 28, 1749-1758. doi: 10.1016/j.neurobiolaging.2006.07.006

*5,6,a Dennis, N. A., Hayes, S. M., Prince, S. E., Madden, D. J., Huettel, S. A., and Cabeza, R. (2008a). Effects of aging on the neural correlates of successful item and source memory encoding. J. Exp. Psychol. Learn. Mem. Cogn. 34, 791-808. doi: 10.1037/0278-7393.34.4.791

*5,6,a Dennis, N. A., Kim, H., and Cabeza, R. (2008b). Age-related differences in brain activity during true and false memory retrieval. J. Cogn. Neurosci. 20, 1390-1402. doi: 10.1162/jocn.2008.20096

${ }^{* 5,6, a}$ Dennis, N. A., Kim, H., and Cabeza, R. (2007b). Effects of aging on true and false memory formation: an fMRI study. Neuropsychologia 45, 3157-3166. doi: 10.1016/j.neuropsychologia.2007.07.003.

D’Esposito, M., Deouell, L. Y., and Gazzaley, A. (2003). Alterations in the BOLD fMRI signal with ageing and disease: a challenge for neuroimaging. Nat. Rev. Neurosci. 4, 863-872. doi: 10.1038/nrn1246

D’Esposito, M., Zarahn, E., Aguirre, G. K., and Rypma, B. (1999). The effect of normal aging on the coupling of neural activity to the bold hemodynamic response. Neuroimage 10, 6-14. doi: 10.1006/nimg.1999.0444

$* 5,6, b, \bullet$ Dickerson, B. C., Salat, D. H., Greve, D. N., Chua, E. F., Rand-Giovannetti, E., Rentz, D. M., et al. (2005). Increased hippocampal activation in mild cognitive impairment compared to normal aging and AD. Neurology 65, 404-411. doi: 10.1212/01.wnl.0000171450.97464.49

*5,6,a, x DiGirolamo, G. J., Kramer, A. F., Barad, V., Cepeda, N. J., Weissman, D. H., Milham, M. P., et al. (2001). General and task-specific frontal lobe recruitment in older adults during executive processes: a fMRI investigation of task-switching. Neuroreport 12, 2065-2071. doi: 10.1097/00001756-200107030-

00054
$* 1,6, b, \mathbf{q}_{\text {Donix, M., Poettrich, K., Weiss, P. H., Werner, A., von Kummer, R., Fink, }}$ G. R., et al. (2010). Age-dependent differences in the neural mechanisms supporting long-term declarative memories. Arch. Clin. Neuropsychol. 25, 383-395. doi: 10.1093/arclin/acq037

*5,6,a Drobyshevsky, A., Baumann, S. B., and Schneider, W. (2006). A rapid fMRI task battery for mapping of visual, motor, cognitive, and emotional function. Neuroimage 31, 732-744. doi: 10.1016/j.neuroimage.2005.12.016

Du, X. L., Edelstein, D., Rossetti, L., Fantus, I. G., Goldberg, H., Ziyadeh, F., et al. (2000). Hyperglycemia-induced mitochondrial superoxide overproduction activates the hexosamine pathway and induces plasminogen activator inhibitor-1 expression by increasing Sp1 glycosylation. Proc. Natl. Acad. Sci. U.S.A. 97, 12222-12226. doi: 10.1073/pnas.97.22.12222

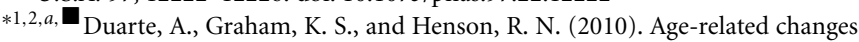
in neural activity associated with familiarity, recollection and false recognition. Neurobiol. Aging 31, 1814-1830. doi: 10.1016/j.neurobiolaging.2008. 09.014

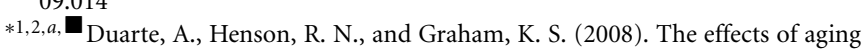
on the neural correlates of subjective and objective recollection. Cereb. Cortex 18, 2169-2180. doi: 10.1093/cercor/bhm243 
${ }^{* 3,5, a}$ Dulas, M. R., and Duarte, A. (2011). The effects of aging on materialindependent and material-dependent neural correlates of contextual binding. Neuroimage 57, 1192-1204. doi: 10.1016/j.neuroimage.2011.05.036

${ }^{* 3,5, a}$ Dulas, M. R., and Duarte, A. (2012). The effects of aging on materialindependent and material-dependent neural correlates of source memory retrieval. Cereb. Cortex 22, 37-50. doi: 10.1093/cercor/bhr056

*7,9,a Duverne, S., Motamedinia, S., and Rugg, M. D. (2009). The relationship between aging, performance, and the neural correlates of successful memory encoding. Cereb. Cortex 19, 733-744. doi: 10.1093/cercor/bhn122

Efimova, I. Y., Efimova, N. Y., Triss, S. V., and Lishmanov, Y. B. (2008). Brain perfusion and cognitive function changes in hypertensive patients. Hypertens. Res. 31, 673-678. doi: 10.1291/hypres.31.673

${ }^{* 1,2, a}$ Emery, L., Heaven, T. J., Paxton, J. L., and Braver, T. S. (2008). Age-related changes in neural activity during performance matched working memory manipulation. Neuroimage 42, 1577-1586. doi: 10.1016/j.neuroimage.2008. 06.021

${ }^{* 7,8, a}$ Erickson, K. I., Colcombe, S. J., Wadhwa, R., Bherer, L., Peterson, M. S., Scalf, P. E., et al. (2007). Training-induced plasticity in older adults: effects of training on hemispheric asymmetry. Neurobiol. Aging 28, 272-283. doi: 10.1016/j.neurobiolaging.2005.12.012

Espeland, M. A., Bryan, R. N., Goveas, J. S., Robinson, J. G., Siddiqui, M. S., Liu, S., et al. (2013). Influence of type 2 diabetes on brain volumes and changes in brain volumes: results from the Women's Health Initiative Magnetic Resonance Imaging studies. Diabetes Care 36, 90-97. doi: 10.2337/dc12-0555

Espeland, M. A., Miller, M. E., Goveas, J. S., Hogan, P. E., Coker, L. H., Williamson, J., et al. (2011). Cognitive function and fine motor speed in older women with diabetes mellitus: results from the women's health initiative study of cognitive aging. J. Womens. Health (Larchmt). 20, 1435-1443. doi: 10.1089/jwh. 2011.2812

Ettorre, E., Cerra, E., Marigliano, B., Vigliotta, M., Vulcano, A., Fossati, C., et al. (2012). Role of cardiovascular risk factors (CRF) in the patients with mild cognitive impairment (MCI). Arch. Gerontol. Geriatr. 54, 330-332. doi: 10.1016/j.archger.2011.04.025

${ }^{* 5,6, a}$ Fakhri, M., Sikaroodi, H., Maleki, F., Ali Oghabian, M., and Ghanaati, H. (2012). Age-related frontal hyperactivation observed across different working memory tasks: an fMRI study. Behav. Neurol. 25, 351-361. doi: 10.3233/BEN2012-120280

$* 4, a, \bullet$ Fera, F., Weickert, T. W., Goldberg, T. E., Tessitore, A., Hariri, A., Das, S., et al. (2005). Neural mechanisms underlying probabilistic category learning in normal aging. J. Neurosci. 25, 11340-11348. doi: 10.1523/JNEUROSCI.273605.2005

${ }^{* 7,9, a}$ Fernandes, M. A., Pacurar, A., Moscovitch, M., and Grady, C. (2006). Neural correlates of auditory recognition under full and divided attention in younger and older adults. Neuropsychologia 44, 2452-2464. doi: 10.1016/j.neuropsychologia.2006.04.020

*2,11,a, ×ilippini, N., Ebmeier, K. P., MacIntosh, B. J., Trachtenberg, A. J., Frisoni, G. B., Wilcock, G. K., et al. (2011). Differential effects of the APOE genotype on brain function across the lifespan. Neuroimage 54, 602-610. doi: 10.1016/j.neuroimage.2010.08.009

$* 2,12, a, \mathbf{\square}, \bullet$ Filippini, N., Nickerson, L. D., Beckmann, C. F., Ebmeier, K. P., Frisoni, G. B., Matthews, P. M., et al. (2012). Age-related adaptations of brain function during a memory task are also present at rest. Neuroimage 59, 3821-3828. doi: 10.1016/j.neuroimage.2011.11.063

Fischer, A. L., de Frias, C. M., Yeung, S. E., and Dixon, R. A. (2009). Short-term longitudinal trends in cognitive performance in older adults with type 2 diabetes. J. Clin. Exp. Neuropsychol. 31, 809-822. doi: 10.1080/13803390802537636

Fontbonne, A., Berr, C., Ducimetière, P., and Alpérovitch, A. (2001). Changes in cognitive abilities over a 4-year period are unfavorably affected in elderly diabetic subjects: results of the Epidemiology of Vascular Aging Study. Diabetes Care 24, 366-370. doi: 10.2337/diacare.24.2.366

${ }^{* 3,5, a}$ Gandini, D., Lemaire, P., Anton, J.-L., and Nazarian, B. (2008). Neural correlates of approximate quantification strategies in young and older adults: an fMRI study. Brain Res. 1246, 144-157. doi: 10.1016/j.brainres.2008.09.096

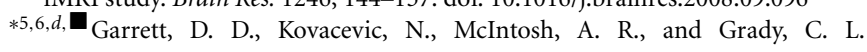
(2011). The importance of being variable. J. Neurosci. 31, 4496-4503. doi: 10.1523/JNEUROSCI.5641-10.2011

$* 3,5, a, \square$ Gazzaley, A., Cooney, J. W., Rissman, J., and D’Esposito, M. (2005). Topdown suppression deficit underlies working memory impairment in normal aging. Nat. Neurosci. 8, 1298-1300. doi: 10.1038/nn1543
Giacco, F., and Brownlee, M. (2010). Oxidative stress and diabetic complications. Circ. Res. 107, 1058-1070. doi: 10.1161/CIRCRESAHA.110.223545

Gifford, K. A., Badaracco, M., Liu, D., Tripodis, Y., Gentile, A., Lu, Z., et al. (2013). Blood pressure and cognition among older adults: a meta-analysis. Arch. Clin. Neuropsychol. 28, 649-664. doi: 10.1093/arclin/act046

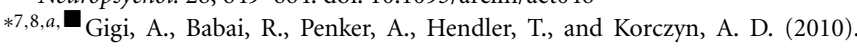
Prefrontal compensatory mechanism may enable normal semantic memory performance in mild cognitive impairment (MCI). J. Neuroimaging 20, 163-168. doi: 10.1111/j.1552-6569.2009.00386.x

Giordano, N., Tikhonoff, V., Palatini, P., Bascelli, A., Boschetti, G., De Lazzari, F., et al. (2012). Cognitive functions and cognitive reserve in relation to blood pressure components in a population-based cohort aged 53 to 94 years. Int. J. Hypertens. 2012:274851. doi: 10.1155/2012/274851

${ }^{* 5,6, a,+}$ Giovanello, K. S., De Brigard, F., Hennessey Ford, J., Kaufer, D. I., Burke, J. R., Browndyke, J. N., et al. (2012). Event-related functional magnetic resonance imaging changes during relational retrieval in normal aging and amnestic mild cognitive impairment. J. Int. Neuropsychol. Soc. 18, 886-897. doi: 10.1017/S1355617712000689

${ }^{* 5,6, a}$ Giovanello, K. S., Kensinger, E. A., Wong, A. T., and Schacter, D. L. (2010). Age-related neural changes during memory conjunction errors. J. Cogn. Neurosci. 22, 1348-1361. doi: 10.1162/jocn.2009.21274

Gold, S. M., Dziobek, I., Sweat, V., Tirsi, A., Rogers, K., Bruehl, H., et al. (2007). Hippocampal damage and memory impairments as possible early brain complications of type 2 diabetes. Diabetologia 50, 711-719. doi: 10.1007/s00125007-0602-7

${ }^{* 5,6, b}$ Gold, B. T., Jiang, Y., Jicha, G. A., and Smith, C. D. (2010a). Functional response in ventral temporal cortex differentiates mild cognitive impairment from normal aging. Hum. Brain Mapp. 31, 1249-1259. doi: 10.1002/hbm. 20932

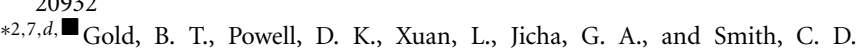
(2010b). Age-related slowing of task switching is associated with decreased integrity of frontoparietal white matter. Neurobiol. Aging 31, 512-522. doi: 10.1016/j.neurobiolaging.2008.04.005

Goldstein, F. C., Levey, A. I., and Steenland, N. K. (2013). High blood pressure and cognitive decline in mild cognitive impairment. J. Am. Geriatr. Soc. 61, 67-73. doi: 10.1111/jgs. 12067

Gorelick, P. B., Scuteri, A., Black, S. E., DeCarli, C., Greenberg, S. M., Iadecola, C., et al. (2011). Vascular contributions to cognitive impairment and dementia: a statement for healthcare professionals from the American Heart Association/American Stroke Association. Stroke 42, 2672-2713. doi: 10.1161/STR.0b013e3182299496

$* 4, a, \bullet$ Gould, R. L., Brown, R. G., Owen, A. M., Ffytche, D. H., and Howard, R. J. (2003). fMRI BOLD response to increasing task difficulty during successful paired associates learning. Neuroimage 20, 1006-1019. doi: 10.1016/S10538119(03)00365-3

${ }^{* 1,9, a}$ Grady, C. L., Grigg, O., and Ng, C. (2012). Age differences in default and reward networks during processing of personally relevant information. Neuropsychologia 50, 1682-1697. doi: 10.1016/j.neuropsychologia.2012.03.024

$* 5,6, d, \square, \bullet$ Grady, C. L., Protzner, A. B., Kovacevic, N., Strother, S. C., Afshin-Pour, B., Wojtowicz, M., et al. (2010). A multivariate analysis of age-related differences in default mode and task-positive networks across multiple cognitive domains. Cereb. Cortex 20, 1432-1447. doi: 10.1093/cercor/bhp207

$* 7,9, a, \mathbf{\square}, \bullet$ Grady, C. L., Springer, M. V., Hongwanishkul, D., McIntosh, A. R., and Winocur, G. (2006). Age-related changes in brain activity across the adult lifespan. J. Cogn. Neurosci. 18, 227-241. doi: 10.1162/089892906775783705

Granic, I., Dolga, A. M., Nijholt, I. M., van Dijk, G., and Eisel, U. L. M. (2009). Inflammation and NF-kappaB in Alzheimer's disease and diabetes. J. Alzheimers Dis. 16, 809-821. doi: 10.3233/JAD-2009-0976

Gregg, E. W., Yaffe, K., Cauley, J. A., Rolka, D. B., Blackwell, T. L., Narayan, K. M., et al. (2000). Is diabetes associated with cognitive impairment and cognitive decline among older women? Study of Osteoporotic Fractures Research Group. Arch. Intern. Med. 160, 174-180. doi: 10.1001/archinte.160.2.174

${ }^{* 5,6, c}$ Grön, G., Bittner, D., Schmitz, B., Wunderlich, A. P., Tomczak, R., and Riepe, M. W. (2003). Variability in memory performance in aged healthy individuals: an fMRI study. Neurobiol. Aging 24, 453-462. doi: 10.1016/S01974580(02)00128-8

$* 6,7, a, \square$ Grossman, M., Cooke, A., DeVita, C., Alsop, D., Detre, J., Chen, W., et al. (2002). Age-related changes in working memory during sentence comprehension: an fMRI study. Neuroimage 15, 302-317. doi: 10.1006/nimg.2001.0971 
Hajjar, I., Zhao, P., Alsop, D., and Novak, V. (2010). Hypertension and cerebral vasoreactivity: a continuous arterial spin labeling magnetic resonance imaging study. Hypertension 56, 859-864. doi: 10.1161/HYPERTENSIONAHA.110. 160002

${ }^{* 5,6, a}$ Hampstead, B. M., Stringer, A. Y., Stilla, R. F., Amaraneni, A., and Sathian, K. (2011). Where did I put that? Patients with amnestic mild cognitive impairment demonstrate widespread reductions in activity during the encoding of ecologically relevant object-location associations. Neuropsychologia 49, 2349-2361. doi: 10.1016/j.neuropsychologia.2011.04.008

${ }^{* 5,6, a}$ Hampstead, B. M., Stringer, A. Y., Stilla, R. F., Giddens, M., and Sathian, K. (2012). Mnemonic strategy training partially restores hippocampal activity in patients with mild cognitive impairment. Hippocampus 22, 1652-1658. doi: 10.1002/hipo.22006

${ }^{* 7,8, a}$ Han, S. D., Arfanakis, K., Fleischman, D. A., Leurgans, S. E., Tuminello, E. R., Edmonds, E. C., et al. (2012a). Functional connectivity variations in mild cognitive impairment: associations with cognitive function. J. Int. Neuropsychol. Soc. 18, 39-48. doi: 10.1017/S1355617711001299

${ }^{* 4, b}$ Han, Y., Lui, S., Kuang, W., Lang, Q., Zou, L., and Jia, J. (2012b). Anatomical and functional deficits in patients with amnestic mild cognitive impairment. PLoS ONE 7:e28664. doi: 10.1371/journal.pone.0028664

Hannesdottir, K., Nitkunan, A., Charlton, R. A., Barrick, T. R., MacGregor, G. A., and Markus, H. S. (2009). Cognitive impairment and white matter damage in hypertension: a pilot study. Acta Neurol. Scand. 119, 261-268. doi: 10.1111/j.1600-0404.2008.01098.x

${ }^{* 7,8, a}$ Hartley, A. A., Jonides, J., and Sylvester, C.-Y. C. (2011). Dual-task processing in younger and older adults: similarities and differences revealed by fMRI. Brain Cogn. 75, 281-291. doi: 10.1016/j.bandc.2011.01.004

$* 3,7, a, \bullet^{\bullet}$ Hedden, T., Van Dijk, K. R. A., Shire, E. H., Sperling, R. A., Johnson, K. A., and Buckner, R. L. (2012). Failure to modulate attentional control in advanced aging linked to white matter pathology. Cereb. Cortex 22, 1038-1051. doi: 10.1093/cercor/bhr172

Heni, M., Schöpfer, P., Peter, A., Sartorius, T., Fritsche, A., Synofzik, M., et al. (2013). Evidence for altered transport of insulin across the blood-brain barrier in insulin-resistant humans. Acta Diabetol. doi: 10.1007/s00592-013-0546-y. [Epub ahead of print].

${ }^{* 5,9, b}$ Holtzer, R., Rakitin, B. C., Steffener, J., Flynn, J., Kumar, A., and Stern, Y. (2009). Age effects on load-dependent brain activations in working memory for novel material. Brain Res. 1249, 148-161. doi: 10.1016/j.brainres.2008.10.009

Hoogenboom, W. S., Marder, T. J., Flores, V. L., Huisman, S., Eaton, H. P., Schneiderman, J. S., et al. (2014). Cerebral white matter integrity and restingstate functional connectivity in middle-aged patients with type 2 diabetes. Diabetes 63, 728-738. doi:10.2337/db13-1219

${ }^{* 5,6, a}$ Hosseini, S. M. H., Rostami, M., Yomogida, Y., Takahashi, M., Tsukiura, T., and Kawashima, R. (2010). Aging and decision making under uncertainty: behavioral and neural evidence for the preservation of decision making in the absence of learning in old age. Neuroimage 52, 1514-1520. doi: 10.1016/j.neuroimage.2010.05.008

${ }^{* 5,6, a}$ Huang, C.-M., Polk, T. A., Goh, J. O., and Park, D. C. (2012). Both left and right posterior parietal activations contribute to compensatory processes in normal aging. Neuropsychologia 50, 55-66. doi: 10.1016/j.neuropsychologia.2011. 10.022

${ }^{* 5,6, a}$ Hubert, V., Beaunieux, H., Chételat, G., Platel, H., Landeau, B., Viader, F., et al. (2009). Age-related changes in the cerebral substrates of cognitive procedural learning. Hum. Brain Mapp. 30, 1374-1386. doi: 10.1002/hbm.20605

$* 4, c, \bullet$ Iidaka, T., Sadato, N., Yamada, H., Murata, T., Omori, M., and Yonekura, Y. (2001). An fMRI study of the functional neuroanatomy of picture encoding in younger and older adults. Brain Res. Cogn. Brain Res. 11, 1-11. doi: 10.1016/S0926-6410(00)00058-6

$* 1,2, b$ Jennings, J. R., van der Veen, F. M., and Meltzer, C. C. (2006). Verbal and spatial working memory in older individuals: a positron emission tomography study. Brain Res. 1092, 177-189. doi: 10.1016/j.brainres.2006.03.077

${ }^{* 1,2, a}$ Jimura, K., and Braver, T. S. (2010). Age-related shifts in brain activity dynamics during task switching. Cereb. Cortex 20, 1420-1431. doi: 10.1093/cercor/bhp206

${ }^{* 5,6, a}$ Jin, M., Pelak, V. S., and Cordes, D. (2012). Aberrant default mode network in subjects with amnestic mild cognitive impairment using resting-state functional MRI. Magn. Reson. Imaging 30, 48-61. doi: 10.1016/j.mri.2011. 07.007
Johnson, E. L. (2012). Glycemic variability in type 2 diabetes mellitus: oxidative stress and macrovascular complications. Adv. Exp. Med. Biol. 771, 139-154.

${ }^{* 5,6, a}$ Johnson, M. K., Mitchell, K. J., Raye, C. L., and Greene, E. J. (2004). An age-related deficit in prefrontal cortical function associated with refreshing information. Psychol. Sci. 15, 127-132. doi: 10.1111/j.0963-7214.2004. 01502009.x

Johnson, J. K., Pa, J., Boxer, A. L., Kramer, J. H., Freeman, K., and Yaffe, K. (2010). Baseline predictors of clinical progression among patients with dysexecutive mild cognitive impairment. Dement. Geriatr. Cogn. Disord. 30, 344-351. doi: $10.1159 / 000318836$

*9,11,a, Johnson, S. C., Schmitz, T. W., Asthana, S., Gluck, M. A., and Myers, C. (2008). Associative learning over trials activates the hippocampus in healthy elderly but not mild cognitive impairment. Neuropsychol. Dev. Cogn. B Aging Neuropsychol. Cogn. 15, 129-145. doi: 10.1080/13825580601139444

*10,12,c Jones, D. T., Machulda, M. M., Vemuri, P., McDade, E. M., Zeng, G., Senjem, M. L., et al. (2011). Age-related changes in the default mode network are more advanced in Alzheimer disease. Neurology 77, 1524-1531. doi: 10.1212/WNL.0b013e318233b33d

Kaiser, N., Sasson, S., Feener, E. P., Boukobza-Vardi, N., Higashi, S., Moller, D. E., et al. (1993). Differential regulation of glucose transport and transporters by glucose in vascular endothelial and smooth muscle cells. Diabetes $42,80-89$. doi: $10.2337 /$ diab. 42.1 .80

Kalani, M. (2008). The importance of endothelin-1 for microvascular dysfunction in diabetes. Vasc. Health Risk Manag. 4, 1061-1068. doi: 10.2147/VHRM.S3920

${ }^{* 5,6, a}$ Kalkstein, J., Checksfield, K., Bollinger, J., and Gazzaley, A. (2011). Diminished top-down control underlies a visual imagery deficit in normal aging. J. Neurosci. 31, 15768-15774. doi: 10.1523/JNEUROSCI.3209-11.2011

Kamiyama, K., Wada, A., Sugihara, M., Kurioka, S., Hayashi, K., Hayashi, T., et al. (2010). Potential hippocampal region atrophy in diabetes mellitus type 2: a voxel-based morphometry VSRAD study. Jpn. J. Radiol. 28, 266-272. doi: 10.1007/s11604-009-0416-2

Kanaya, A. M., Barrett-Connor, E., Gildengorin, G., and Yaffe, K. (2004). Change in cognitive function by glucose tolerance status in older adults: a 4-year prospective study of the Rancho Bernardo study cohort. Arch. Intern. Med. 164, 1327-1333. doi: 10.1001/archinte.164.12.1327

${ }^{* 5,6, a, \circ}{ }^{K}$ Kannurpatti, S. S., Motes, M. A., Rypma, B., and Biswal, B. B. (2010). Neural and vascular variability and the fMRI-BOLD response in normal aging. Magn. Reson. Imaging 28, 466-476. doi: 10.1016/j.mri.2009.12.007

${ }^{* 5,6, a, \circ}{ }^{\circ}$ Kannurpatti, S. S., Motes, M. A., Rypma, B., and Biswal, B. B. (2011). Increasing measurement accuracy of age-related BOLD signal change: minimizing vascular contributions by resting-state-fluctuation-of-amplitude scaling. Hum. Brain Mapp. 32, 1125-1140. doi: 10.1002/hbm.21097

${ }^{* 5,6, a}$ Kaufmann, L., Ischebeck, A., Weiss, E., Koppelstaetter, F., Siedentopf, C., Vogel, S. E., et al. (2008). An fMRI study of the numerical Stroop task in individuals with and without minimal cognitive impairment. Cortex 44, 1248-1255. doi: 10.1016/j.cortex.2007.11.009

Kearney, P. M., Whelton, M., Reynolds, K., Muntner, P., Whelton, P. K., and He, J. (2005). Global burden of hypertension: analysis of worldwide data. Lancet 365, 217-223. doi: 10.1016/S0140-6736(05)17741-1

Kennedy, K. M., and Raz, N. (2009). Pattern of normal age-related regional differences in white matter microstructure is modified by vascular risk. Brain Res. 1297, 41-56. doi: 10.1016/j.brainres.2009.08.058

${ }^{* 7,8, a}$ Kennedy, K. M., Rodrigue, K. M., Devous, M. D. Sr., Hebrank, A. C., Bischof, G. N., and Park, D. C. (2012). Effects of beta-amyloid accumulation on neural function during encoding across the adult lifespan. Neuroimage 62, 1-8. doi: 10.1016/j.neuroimage.2012.03.077

Kerti, L., Witte, A. V., Winkler, A., Grittner, U., Rujescu, D., and Floel, A. (2013). Higher glucose levels associated with lower memory and reduced hippocampal microstructure. Neurology 81, 1746-1752. doi: 10.1212/01.wnl.0000435561. 00234.ee

$* 9,11, a, \mathbf{\square}, \times$ Kikuchi, M., Hirosawa, T., Yokokura, M., Yagi, S., Mori, N., Yoshikawa, E., et al. (2011). Effects of brain amyloid deposition and reduced glucose metabolism on the default mode of brain function in normal aging. J. Neurosci. 31, 11193-11199. doi: 10.1523/JNEUROSCI.2535-11.2011

Kim, E., Cho, M. H., Cha, K. R., Park, J. S., Ahn, C.-W., Oh, B. H., et al. (2008). Interactive effect of central obesity and hypertension on cognitive function in older out-patients with Type 2 diabetes. Diabet. Med. 25, 1440-1446. doi: 10.1111/j.1464-5491.2008.02612.x 
${ }^{* 6,7, a}$ Kim, S.-Y., and Giovanello, K. S. (2011). The effects of attention on agerelated relational memory deficits: fMRI evidence from a novel attentional manipulation. J. Cogn. Neurosci. 23, 3637-3656. doi: 10.1162/jocn_a_00058

${ }^{* 4, b}$ Kircher, T., Weis, S., Leube, D., Freymann, K., Erb, M., Jessen, F., et al. (2008). Anterior hippocampus orchestrates successful encoding and retrieval of non-relational memory: an event-related fMRI study. Eur. Arch. Psychiatry Clin. Neurosci. 258, 363-372. doi: 10.1007/s00406-008-0805-z

${ }^{* 1,9, a}$ Kirchhoff, B. A., Anderson, B. A., Barch, D. M., and Jacoby, L. L. (2012). Cognitive and neural effects of semantic encoding strategy training in older adults. Cereb. Cortex 22, 788-799. doi: 10.1093/cercor/bhr129

Kitagawa, K., Oku, N., Kimura, Y., Yagita, Y., Sakaguchi, M., Hatazawa, J., et al. (2009). Relationship between cerebral blood flow and later cognitive decline in hypertensive patients with cerebral small vessel disease. Hypertens. Res. 32, 816-820. doi: 10.1038/hr.2009.100

Kloppenborg, R. P., van den Berg, E., Kappelle, L. J., and Biessels, G. J. (2008). Diabetes and other vascular risk factors for dementia: which factor matters most? A systematic review. Eur. J. Pharmacol. 585, 97-108. doi: 10.1016/j.ejphar.2008.02.049

${ }^{* 2,5, a}$ Klostermann, E. C., Braskie, M. N., Landau, S. M., O’Neil, J. P., and Jagust, W. J. (2012). Dopamine and frontostriatal networks in cognitive aging. Neurobiol. Aging 33, 623.e15-24. doi: 10.1016/j.neurobiolaging.2011.03.002

Knecht, S., Wersching, H., Lohmann, H., Berger, K., and Ringelstein, E. B. (2009) How much does hypertension affect cognition? Explained variance in crosssectional analysis of non-demented community-dwelling individuals in the SEARCH study. J. Neurol. Sci. 283, 149-152. doi: 10.1016/j.jns.2009.02.362

Knecht, S., Wersching, H., Lohmann, H., Bruchmann, M., Duning, T., Dziewas, R., et al. (2008). High-normal blood pressure is associated with poor cognitive performance. Hypertension 51, 663-668. doi: 10.1161/HYPERTENSIONAHA. 107.105577

$* 7,8, b, \bullet$ Koch, W., Teipel, S., Mueller, S., Buerger, K., Bokde, A. L. W., Hampel, H., et al. (2010). Effects of aging on default mode network activity in resting state fMRI: does the method of analysis matter? Neuroimage 51, 280-287. doi: 10.1016/j.neuroimage.2009.12.008

${ }^{* 7,8, a}$ Krause, J. B., Taylor, J. G., Schmidt, D., Hautzel, H., Mottaghy, F. M., and Müller-Gärtner, H. W. (2000). Imaging and neural modelling in episodic and working memory processes. Neural Netw. 13, 847-859

${ }^{* 1,9, a}$ Kühn, S., Schmiedek, F., Schott, B., Ratcliff, R., Heinze, H.-J., Düzel, E., et al. (2011). Brain areas consistently linked to individual differences in perceptual decision-making in younger as well as older adults before and after training. J. Cogn. Neurosci. 23, 2147-2158. doi: 10.1162/jocn.2010.21564

${ }^{* 7,8, a}$ Kukolja, J., Thiel, C. M., Wilms, M., Mirzazade, S., and Fink, G. R. (2009). Ageing-related changes of neural activity associated with spatial contextual memory. Neurobiol. Aging 30, 630-645. doi: 10.1016/j.neurobiolaging.2007. 08.015

${ }^{* 6,7, a}$ Kukolja, J., Thiel, C. M., Wolf, O. T., and Fink, G. R. (2008). Increased cortisol levels in cognitively challenging situations are beneficial in young but not older subjects. Psychopharmacology (Berl.) 201, 293-304. doi: 10.1007/s00213008-1275-8

$* 1,2, a, \bullet$ Lamar, M., Yousem, D. M., and Resnick, S. M. (2004). Age differences in orbitofrontal activation: an fMRI investigation of delayed match and nonmatch to sample. Neuroimage 21, 1368-1376. doi: 10.1016/j.neuroimage.2003. 11.018

${ }^{* 7,8, a}$ Langenecker, S. A., Briceno, E. M., Hamid, N. M., and Nielson, K. A. (2007). An evaluation of distinct volumetric and functional MRI contributions toward understanding age and task performance: a study in the basal ganglia. Brain Res. 1135, 58-68. doi: 10.1016/j.brainres.2006.11.068

${ }^{* 5,6, a}$ Langenecker, S. A., and Nielson, K. A. (2003). Frontal recruitment during response inhibition in older adults replicated with fMRI. Neuroimage 20, 1384-1392. doi: 10.1016/S1053-8119(03)00372-0

${ }^{* 5,6, a}$ Langenecker, S. A., Nielson, K. A., and Rao, S. M. (2004). fMRI of healthy older adults during Stroop interference. Neuroimage 21, 192-200. doi: 10.1016/j.neuroimage.2003.08.027

Last, D., Alsop, D. C., Abduljalil, A. M., Marquis, R. P., de Bazelaire, C., Hu, K., et al. (2007). Global and regional effects of type 2 diabetes on brain tissue volumes and cerebral vasoreactivity. Diabetes Care 30, 1193-1199. doi: $10.2337 / \mathrm{dc} 06-2052$

Launer, L. J., Ross, G. W., Petrovitch, H., Masaki, K., Foley, D., White, L. R., et al. (2000). Midlife blood pressure and dementia: the Honolulu-Asia aging study. Neurobiol. Aging 21, 49-55. doi: 10.1016/S0197-4580(00)00096-8
Lee, J. H., Yoon, S., Renshaw, P. F., Kim, T.-S., Jung, J. J., Choi, Y., et al. (2013). Morphometric changes in lateral ventricles of patients with recent-onset type 2 diabetes mellitus. PLoS ONE 8:e60515. doi: 10.1371/journal.pone.0060515

${ }^{* 5,6, a}$ Leshikar, E. D., Gutchess, A. H., Hebrank, A. C., Sutton, B. P., and Park, D. C. (2010). The impact of increased relational encoding demands on frontal and hippocampal function in older adults. Cortex 46, 507-521. doi: 10.1016/j.cortex.2009.07.011

*5,6,a Li, C., Zheng, J., Wang, J., Gui, L., and Li, C. (2009a). An fMRI stroop task study of prefrontal cortical function in normal aging, mild cognitive impairment, and Alzheimer's disease. Curr. Alzheimer Res. 6, 525-530. doi: $10.2174 / 156720509790147142$

Li, J., Wang, Y. J., Zhang, M., Xu, Z. Q., Gao, C. Y., Fang, C. Q., et al. (2011). Vascular risk factors promote conversion from mild cognitive impairment to Alzheimer disease. Neurology 76, 1485-1491. doi: 10.1212/WNL.0b013e318217e7a4

${ }^{* 7,8, a} \mathrm{Li}$, Z., Moore, A. B., Tyner, C., and Hu, X. (2009b). Asymmetric connectivity reduction and its relationship to "HAROLD" in aging brain. Brain Res. 1295, 149-158. doi: 10.1016/j.brainres.2009.08.004

Logothetis, N. K., Pauls, J., Augath, M., Trinath, T., and Oeltermann, A. (2001). Neurophysiological investigation of the basis of the fMRI signal. Nature 412, 150-157. doi: 10.1038/35084005

Luchsinger, J. A. (2008). Adiposity, hyperinsulinemia, diabetes and Alzheimer's disease: an epidemiological perspective. Eur. J. Pharmacol. 585, 119-129. doi: 10.1016/j.ejphar.2008.02.048

Luchsinger, J. A., Palmas, W., Teresi, J. A., Silver, S., Kong, J., Eimicke, J. P., et al. (2011). Improved diabetes control in the elderly delays global cognitive decline. J. Nutr. Health Aging 15, 445-449. doi: 10.1007/s12603-011-0057-x

${ }^{* 3,5, a}$ MacDonald, S. W. S., Nyberg, L., Sandblom, J., Fischer, H., and Bäckman, L. (2008). Increased response-time variability is associated with reduced inferior parietal activation during episodic recognition in aging. J. Cogn. Neurosci. 20, 779-786. doi: 10.1162/jocn.2008.20502

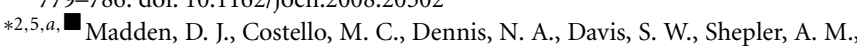
Spaniol, J., et al. (2010). Adult age differences in functional connectivity during executive control. Neuroimage 52, 643-657. doi: 10.1016/j.neuroimage.2010.

04.249
$* 1,2, d,{ }_{\text {Madden, D. J., Langley, L. K., Denny, L. L., Turkington, T. G., Provenzale, J. }}$ M., Hawk, T. C., et al. (2002a). Adult age differences in visual word identification: functional neuroanatomy by positron emission tomography. Brain Cogn. 49, 297-321. doi: 10.1006/brcg.2001.1502

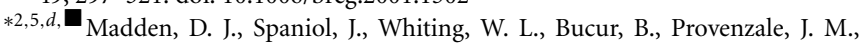
Cabeza, R., et al. (2007). Adult age differences in the functional neuroanatomy of visual attention: a combined fMRI and DTI study. Neurobiol. Aging 28, 459-476. doi: 10.1016/j.neurobiolaging.2006.01.005

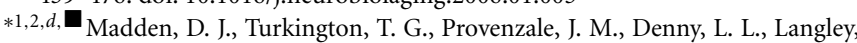
L. K., Hawk, T. C., et al. (2002b). Aging and attentional guidance during visual search: functional neuroanatomy by positron emission tomography. Psychol. Aging 17, 24-43. doi: 10.1037/0882-7974.17.1.24

Maggi, S., Limongi, F., Noale, M., Romanato, G., Tonin, P., Rozzini, R., et al. (2009). Diabetes as a risk factor for cognitive decline in older patients. Dement. Geriatr. Cogn. Disord. 27, 24-33. doi: 10.1159/000183842

$* 1,9, a$ Maillet, D., and Rajah, M. N. (2011). Age-related changes in the three-way correlation between anterior hippocampus volume, whole-brain patterns of encoding activity and subsequent context retrieval. Brain Res. 1420, 68-79. doi: 10.1016/j.brainres.2011.08.071

Marioni, R. E., Strachan, M. W. J., Reynolds, R. M., Lowe, G. D. O., Mitchell, R. J., Fowkes, F. G. R., et al. (2010). Association between raised inflammatory markers and cognitive decline in elderly people with type 2 diabetes: the Edinburgh Type 2 Diabetes Study. Diabetes 59, 710-713. doi: 10.2337/db09-1163

${ }^{* 3,5, b}$ Mathis, A., Schunck, T., Erb, G., Namer, I. J., and Luthringer, R. (2009). The effect of aging on the inhibitory function in middle-aged subjects: a functional MRI study coupled with a color-matched Stroop task. Int. J. Geriatr. Psychiatry 24, 1062-1071. doi: 10.1002/gps.2222

${ }^{* 4, a}$ Mattay, V. S., Fera, F., Tessitore, A., Hariri, A. R., Berman, K. F., Das, S., et al. (2006). Neurophysiological correlates of age-related changes in working memory capacity. Neurosci. Lett. 392, 32-37. doi: 10.1016/j.neulet.2005. 09.025

*1,2,a, $\bullet$ Matthäus, F., Schmidt, J.-P., Banerjee, A., Schulze, T. G., Demirakca, T., and Diener, C. (2012). Effects of age on the structure of functional connectivity networks during episodic and working memory demand. Brain Connect. 2, 113-124. doi: 10.1089/brain.2012.0077 


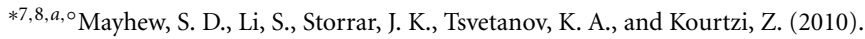
Learning shapes the representation of visual categories in the aging human brain. J. Cogn. Neurosci. 22, 2899-2912. doi: 10.1162/jocn.2010.21415

$* 7,8, a, \square$ McGeown, W. J., Shanks, M. F., Forbes-McKay, K. E., and Venneri, A. (2009). Patterns of brain activity during a semantic task differentiate normal aging from early Alzheimer's disease. Psychiatry Res. 173, 218-227. doi: 10.1016/j.pscychresns.2008.10.005

$* 5,6, a$ Meier, T. B., Desphande, A. S., Vergun, S., Nair, V. A., Song, J., Biswal, B. B., et al. (2012). Support vector machine classification and characterization of agerelated reorganization of functional brain networks. Neuroimage 60, 601-613. doi: 10.1016/j.neuroimage.2011.12.052

${ }^{* 7,9, c}$ Meinzer, M., Flaisch, T., Seeds, L., Harnish, S., Antonenko, D., Witte, V., et al. (2012a). Same modulation but different starting points: performance modulates age differences in inferior frontal cortex activity during word-retrieval. PLoS ONE 7:e33631. doi: 10.1371/journal.pone.0033631

*5,6,d Meinzer, M., Flaisch, T., Wilser, L., Eulitz, C., Rockstroh, B., Conway, T., et al. (2009). Neural signatures of semantic and phonemic fluency in young and old adults. J. Cogn. Neurosci. 21, 2007-2018. doi: 10.1162/jocn.2009.21219

${ }^{* 7,9, c}$ Meinzer, M., Seeds, L., Flaisch, T., Harnish, S., Cohen, M. L., McGregor, K., et al. (2012b). Impact of changed positive and negative task-related brain activity on word-retrieval in aging. Neurobiol. Aging 33, 656-669. doi: 10.1016/j.neurobiolaging.2010.06.020

Messier, C., Awad-Shimoon, N., Gagnon, M., Desrochers, A., and Tsiakas, M. (2011). Glucose regulation is associated with cognitive performance in young nondiabetic adults. Behav. Brain Res. 222, 81-88. doi: 10.1016/j.bbr.2011.03.023

Messier, C., Tsiakas, M., Gagnon, M., and Desrochers, A. (2010). Effect of age and glucoregulation on cognitive performance. J. Clin. Exp. Neuropsychol. 32, 809-821. doi: 10.1080/13803390903540323

${ }^{* 7,9, a}$ Meulenbroek, O., Kessels, R. P. C., de Rover, M., Petersson, K. M., Rikkert, M. G. M. O., Rijpkema, M., et al. (2010a). Age-effects on associative object-location memory. Brain Res. 1315, 100-110. doi: 10.1016/j.brainres.2009.12.011

${ }^{* 1,2, a}$ Meulenbroek, O., Petersson, K. M., Voermans, N., Weber, B., and Fernández, G. (2004). Age differences in neural correlates of route encoding and route recognition. Neuroimage 22, 1503-1514. doi: 10.1016/j.neuroimage.2004.04.007

${ }^{* 7,8, a}$ Meulenbroek, O., Rijpkema, M., Kessels, R. P. C., Rikkert, M. G. M. O., and Fernández, G. (2010b). Autobiographical memory retrieval in patients with Alzheimer's disease. Neuroimage 53, 331-340. doi: 10.1016/j.neuroimage.2010.05.082

*7,8,b, Miettinen, P. S., Pihlajamäki, M., Jauhiainen, A. M., Niskanen, E., Hänninen, T., Vanninen, R., et al. (2011). Structure and function of medial temporal and posteromedial cortices in early Alzheimer's disease. Eur. J. Neurosci. 34, 320-330. doi: 10.1111/j.1460-9568.2011.07745.x

$* 3,7, a, \bullet$ Milham, M. P., Erickson, K. I., Banich, M. T., Kramer, A. F., Webb, A., Wszalek, T., et al. (2002). Attentional control in the aging brain: insights from an fMRI study of the stroop task. Brain Cogn. 49, 277-296. doi: 10.1006/brcg.2001.1501

${ }^{* 5,6, a}$ Mitchell, K. J., Johnson, M. K., Raye, C. L., and D’Esposito, M. (2000). fMRI evidence of age-related hippocampal dysfunction in feature binding in working memory. Brain Res. Cogn. Brain Res. 10, 197-206. doi: 10.1016/S09266410(00)00029-X

${ }^{* 7,8, a}$ Mitchell, K. J., Johnson, M. R., Higgins, J. A., and Johnson, M. K. (2010). Age differences in brain activity during perceptual versus reflective attention. Neuroreport 21, 293-297. doi: 10.1097/WNR.0b013e32833730d6

${ }^{* 7,8, a}$ Mitchell, K. J., Raye, C. L., Johnson, M. K., and Greene, E. J. (2006). An fMRI investigation of short-term source memory in young and older adults. Neuroimage 30, 627-633. doi: 10.1016/j.neuroimage.2005.09.039

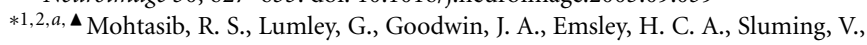
and Parkes, L. M. (2012). Calibrated fMRI during a cognitive Stroop task reveals reduced metabolic response with increasing age. Neuroimage 59, 1143-1151. doi: 10.1016/j.neuroimage.2011.07.092

Moran, C., Phan, T. G., Chen, J., Blizzard, L., Beare, R., Venn, A., et al. (2013). Brain atrophy in type 2 diabetes: regional distribution and influence on cognition. Diabetes Care 36, 4036-4042. doi: 10.2337/dc13-0143

*3,5,a Morcom, A. M., and Friston, K. J. (2012). Decoding episodic memory in ageing: a Bayesian analysis of activity patterns predicting memory. Neuroimage 59, 1772-1782. doi: 10.1016/j.neuroimage.2011.08.071

$* 3,5, a, \square$ Morcom, A. M., Good, C. D., Frackowiak, R. S. J., and Rugg, M. D. (2003). Age effects on the neural correlates of successful memory encoding. Brain 126, 213-229. doi: 10.1093/brain/awg020 *5,6,a Mormino, E. C., Brandel, M. G., Madison, C. M., Marks, S., Baker, S. L., and Jagust, W. J. (2012). A $\beta$ Deposition in aging is associated with increases in brain activation during successful memory encoding. Cereb. Cortex 22, 1813-1823. doi: 10.1093/cercor/bhr255

${ }^{* 5,6, a}$ Mormino, E. C., Smiljic, A., Hayenga, A. O., Onami, S. H., Greicius, M. D., Rabinovici, G. D., et al. (2011). Relationships between $\beta$-amyloid and functional connectivity in different components of the default mode network in aging. Cereb. Cortex 21, 2399-2407. doi: 10.1093/cercor/bhr025

Morris, J. K., Vidoni, E. D., Honea, R. A., and Burns, J. M. (2014). Impaired glycemia increases disease progression in mild cognitive impairment. Neurobiol. Aging 35, 585-589. doi: 10.1016/j.neurobiolaging.2013.09.033

*5,6,a Mowinckel, A. M., Espeseth, T., and Westlye, L. T. (2012). Network-specific effects of age and in-scanner subject motion: a resting-state fMRI study of 238 healthy adults. Neuroimage 63, 1364-1373. doi: 10.1016/j.neuroimage.2012. 08.004

*5,6,a Murphy, K., and Garavan, H. (2004). Artifactual fMRI group and condition differences driven by performance confounds. Neuroimage 21, 219-228. doi: 10.1016/j.neuroimage.2003.09.016

${ }^{* 3,7, b}$ Murty, V. P., Sambataro, F., Das, S., Tan, H.-Y., Callicott, J. H., Goldberg, T. E., et al. (2009). Age-related alterations in simple declarative memory and the effect of negative stimulus valence. J. Cogn. Neurosci. 21, 1920-1933. doi: 10.1162/jocn.2009.21130

Musen, G., Jacobson, A. M., Bolo, N. R., Simonson, D. C., Shenton, M. E., McCartney, R. L., et al. (2012). Resting-state brain functional connectivity is altered in type 2 diabetes. Diabetes 61, 2375-2379. doi: 10.2337/db11-1669

Nagai, M., Hoshide, S., Ishikawa, J., Shimada, K., and Kario, K. (2008). Ambulatory blood pressure as an independent determinant of brain atrophy and cognitive function in elderly hypertension. J. Hypertens. 26, 1636-1641. doi: 10.1097/HJH.0b013e3283018333

*7,8,a Nagel, I. E., Preuschhof, C., Li, S.-C., Nyberg, L., Bäckman, L., Lindenberger, U., et al. (2009). Performance level modulates adult age differences in brain activation during spatial working memory. Proc. Natl. Acad. Sci. U.S.A. 106, 22552-22557. doi: 10.1073/pnas.0908238106

*10,12,a Nagel, I. E., Preuschhof, C., Li, S.-C., Nyberg, L., Bäckman, L., Lindenberger, U., et al. (2011). Load modulation of BOLD response and connectivity predicts working memory performance in younger and older adults. J. Cogn. Neurosci. 23, 2030-2045. doi: 10.1162/jocn.2010.21560

Nakae, J., Kido, Y., and Accili, D. (2001). Distinct and overlapping functions of insulin and IGF-I receptors. Endocr. Rev. 22, 818-835. doi: 10.1210/edrv.22.6.0452

Newcomer, J. W., and Haupt, D. W. (2006). The metabolic effects of antipsychotic medications. Can. J. Psychiatry 51, 480-491.

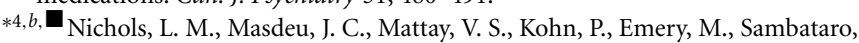
F., et al. (2012). Interactive effect of apolipoprotein e genotype and age on hippocampal activation during memory processing in healthy adults. Arch. Gen. Psychiatry 69, 804-813. doi: 10.1001/archgenpsychiatry.2011.1893

$* 7,8, a, \bullet$ Nielson, K. A., Douville, K. L., Seidenberg, M., Woodard, J. L., Miller, S. K., Franczak, M., et al. (2006). Age-related functional recruitment for famous name recognition: an event-related fMRI study. Neurobiol. Aging 27, 1494-1504. doi: 10.1016/j.neurobiolaging.2005.08.022

${ }^{* 5,6, a}$ Nielson, K. A., Langenecker, S. A., and Garavan, H. (2002). Differences in the functional neuroanatomy of inhibitory control across the adult life span. Psychol. Aging 17, 56-71. doi: 10.1037/0882-7974.17.1.56

$* 3,5, a, \square$ Nielson, K. A., Langenecker, S. A., Ross, T. J., Garavan, H., Rao, S. M., and Stein, E. A. (2004). Comparability of functional MRI response in young and old during inhibition. Neuroreport 15, 129-133. doi: 10.1097/00001756-20040119000025

Nishikawa, T., Edelstein, D., Du, X. L., Yamagishi, S., Matsumura, T., Kaneda, Y., et al. (2000). Normalizing mitochondrial superoxide production blocks three pathways of hyperglycaemic damage. Nature 404, 787-790. doi: $10.1038 / 35008121$

Nooyens, A. C. J., Baan, C. A., Spijkerman, A. M. W., and Verschuren, W. M. M. (2010). Type 2 diabetes and cognitive decline in middle-aged men and women: the Doetinchem Cohort Study. Diabetes Care 33, 1964-1969. doi: 10.2337/ dc09-2038

*7,10,c, Nordahl, C. W., Ranganath, C., Yonelinas, A. P., Decarli, C., Fletcher, E., and Jagust, W. J. (2006). White matter changes compromise prefrontal cortex function in healthy elderly individuals. J. Cogn. Neurosci. 18, 418-429. doi: $10.1162 / 089892906775990552$ 
Novak, V., Last, D., Alsop, D. C., Abduljalil, A. M., Hu, K., Lepicovsky, L., et al. (2006). Cerebral blood flow velocity and periventricular white matter hyperintensities in type 2 diabetes. Diabetes Care 29, 1529-1534. doi: $10.2337 / \mathrm{dc} 06-0261$

*5,6,a Nyberg, L., Dahlin, E., Stigsdotter Neely, A., and Bäckman, L. (2009). Neural correlates of variable working memory load across adult age and skill: dissociative patterns within the fronto-parietal network. Scand. J. Psychol. 50, 41-46. doi: 10.1111/j.1467-9450.2008.00678.x

$* 7,8, a, \bullet$ O’Brien, J. L., O’Keefe, K. M., LaViolette, P. S., DeLuca, A. N., Blacker, D., Dickerson, B. C., et al. (2010). Longitudinal fMRI in elderly reveals loss of hippocampal activation with clinical decline. Neurology 74, 1969-1976. doi: 10.1212/WNL.0b013e3181e3966e

${ }^{* 7,8, a}$ Osaka, M., Otsuka, Y., and Osaka, N. (2012a). Verbal to visual code switching improves working memory in older adults: an fMRI study. Front. Hum. Neurosci. 6:24. doi: 10.3389/fnhum.2012.00024

*7,8, a Osaka, M., Yaoi, K., Otsuka, Y., Katsuhara, M., and Osaka, N. (2012b). Practice on conflict tasks promotes executive function of working memory in the elderly. Behav. Brain Res. 233, 90-98. doi: 10.1016/j.bbr.2012.04.044

*7,8,a Otsuka, Y., Osaka, N., Morishita, M., Kondo, H., and Osaka, M. (2006). Decreased activation of anterior cingulate cortex in the working memory of the elderly. Neuroreport 17, 1479-1482. doi: 10.1097/01.wnr.0000236852. $63092.9 f$

Oveisgharan, S., and Hachinski, V. (2010). Hypertension, executive dysfunction, and progression to dementia: the canadian study of health and aging. Arch. Neurol. 67, 187-192. doi: 10.1001/archneurol.2009.312

*6,7,a Pacheco, J., Beevers, C. G., McGeary, J. E., and Schnyer, D. M. (2012). Memory monitoring performance and PFC activity are associated with 5HTTLPR genotype in older adults. Neuropsychologia 50, 2257-2270. doi: 10.1016/j.neuropsychologia.2012.05.030

*7,8,a Park, D. C., Welsh, R. C., Marshuetz, C., Gutchess, A. H., Mikels, J., Polk, T. A., et al. (2003). Working memory for complex scenes: age differences in frontal and hippocampal activations. J. Cogn. Neurosci. 15, 1122-1134. doi: 10.1162/089892903322598094

$* 4, a, \square$ Park, J., Carp, J., Hebrank, A., Park, D. C., and Polk, T. A. (2010). Neural specificity predicts fluid processing ability in older adults. J. Neurosci. 30, 9253-9259. doi: 10.1523/JNEUROSCI.0853-10.2010

*1,2,a Paxton, J. L., Barch, D. M., Racine, C. A., and Braver, T. S. (2008). Cognitive control, goal maintenance, and prefrontal function in healthy aging. Cereb. Cortex 18, 1010-1028. doi: 10.1093/cercor/bhm135

*1,9,b Persson, J., Kalpouzos, G., Nilsson, L.-G., Ryberg, M., and Nyberg, L. (2011). Preserved hippocampus activation in normal aging as revealed by fMRI. Hippocampus 21, 753-766. doi: 10.1002/hipo.20794

*7,10,a,+ Persson, J., Nyberg, L., Lind, J., Larsson, A., Nilsson, L.-G., Ingvar, M., et al. (2006). Structure-function correlates of cognitive decline in aging. Cereb. Cortex 16, 907-915. doi: 10.1093/cercor/bhj036

$* 7,10, c$ Persson, J., Pudas, S., Lind, J., Kauppi, K., Nilsson, L.-G., and Nyberg, L. (2012). Longitudinal structure-function correlates in elderly reveal MTL dysfunction with cognitive decline. Cereb. Cortex 22, 2297-2304. doi: 10.1093/cercor/bhr306

*2,5,a Persson, J., Sylvester, C.-Y. C., Nelson, J. K., Welsh, K. M., Jonides, J., and Reuter-Lorenz, P. A. (2004). Selection requirements during verb generation: differential recruitment in older and younger adults. Neuroimage 23, 1382-1390. doi: 10.1016/j.neuroimage.2004.08.004

*7,8,a Petrella, J. R., Townsend, B. A., Jha, A. P., Ziajko, L. A., Slavin, M. J., Lustig, C., et al. (2005). Increasing memory load modulates regional brain activity in older adults as measured by fMRI. J. Neuropsychiatry Clin. Neurosci. 17, 75-83. doi: 10.1176/appi.neuropsych.17.1.75

${ }^{* 5,6, a}$ Piefke, M., Onur, Ö. A., and Fink, G. R. (2012). Aging-related changes of neural mechanisms underlying visual-spatial working memory. Neurobiol. Aging 33, 1284-1297. doi: 10.1016/j.neurobiolaging.2010.10.014

${ }^{* 7,8, a}$ Pihlajamäki, M., and Sperling, R. A. (2009). Functional MRI assessment of task-induced deactivation of the default mode network in Alzheimer's disease and at-risk older individuals. Behav. Neurol. 21, 77-91. doi: 10.3233/BEN-20090231

Pires, P. W., Dams Ramos, C. M., Matin, N., and Dorrance, A. M. (2013). The effects of hypertension on the cerebral circulation. Am. J. Physiol. Heart Circ. Physiol. 304, H1598-H1614. doi: 10.1152/ajpheart.00490.2012

*4,c Podell, J. E., Sambataro, F., Murty, V. P., Emery, M. R., Tong, Y., Das, S., et al. (2012). Neurophysiological correlates of age-related changes in working memory updating. Neuroimage 62, 2151-2160. doi: 10.1016/j.neuroimage.2012.05.066

${ }^{* 7,8, a}$ Prakash, R. S., Erickson, K. I., Colcombe, S. J., Kim, J. S., Voss, M. W., and Kramer, A. F. (2009). Age-related differences in the involvement of the prefrontal cortex in attentional control. Brain Cogn. 71, 328-335. doi: 10.1016/j.bandc.2009.07.005

*7,8,a Protzner, A. B., Mandzia, J. L., Black, S. E., and McAndrews, M. P. (2011). Network interactions explain effective encoding in the context of medial temporal damage in MCI. Hum. Brain Mapp. 32, 1277-1289. doi: 10.1002/hbm. 21107

*7,8,a,•Putcha, D., O’Keefe, K., LaViolette, P., O’Brien, J., Greve, D., Rentz, D. M. et al. (2011). Reliability of functional magnetic resonance imaging associative encoding memory paradigms in non-demented elderly adults. Hum. Brain Mapp. 32, 2027-2044. doi: 10.1002/hbm.21166

$* 1,9, d$ Rajah, M. N., Languay, R., and Grady, C. L. (2011). Age-related changes in right middle frontal gyrus volume correlate with altered episodic retrieval activity. J. Neurosci. 31, 17941-17954. doi: 10.1523/JNEUROSCI.1690-11.2011

$* 7,8, a, \bullet$ Rajah, M. N., Languay, R., and Valiquette, L. (2010). Age-related changes in prefrontal cortex activity are associated with behavioural deficits in both temporal and spatial context memory retrieval in older adults. Cortex 46, 535-549. doi: 10.1016/j.cortex.2009.07.006

$* 5,6, a, \square$ Rajah, M. N., and McIntosh, A. R. (2008). Age-related differences in brain activity during verbal recency memory. Brain Res. 1199, 111-125. doi: 10.1016/j.brainres.2007.12.051

Raji, C. A., Lopez, O. L., Kuller, L. H., Carmichael, O. T., Longstreth, W. T. Jr., Gach, H. M., et al. (2012). White matter lesions and brain gray matter volume in cognitively normal elders. Neurobiol. Aging 33, 834.e7-16. doi: 10.1016/j.neurobiolaging.2011.08.010

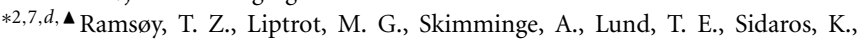
Christensen, M. S., et al. (2012). Healthy aging attenuates task-related specialization in the human medial temporal lobe. Neurobiol. Aging 33, 1874-1889. doi: 10.1016/j.neurobiolaging.2011.09.032

${ }^{* 6,7, a}$ Rand-Giovannetti, E., Chua, E. F., Driscoll, A. E., Schacter, D. L., Albert, M. S., and Sperling, R. A. (2006). Hippocampal and neocortical activation during repetitive encoding in older persons. Neurobiol. Aging 27, 173-182. doi: 10.1016/j.neurobiolaging.2004.12.013

Ravona-Springer, R., Moshier, E., Schmeidler, J., Godbold, J., Akrivos, J., Rapp, M., et al. (2012). Changes in glycemic control are associated with changes in cognition in non-diabetic elderly. J. Alzheimers Dis. 30, 299-309. doi: 10.3233/JAD-2012-120106

${ }^{* 5,6, a}$ Raye, C. L., Mitchell, K. J., Reeder, J. A., Greene, E. J., and Johnson, M. K. (2008). Refreshing one of several active representations: behavioral and functional magnetic resonance imaging differences between young and older adults. J. Cogn. Neurosci. 20, 852-862. doi: 10.1162/jocn.2008.20508

Raz, N., Yang, Y., Dahle, C. L., and Land, S. (2012). Volume of white matter hyperintensities in healthy adults: contribution of age, vascular risk factors, and inflammation-related genetic variants. Biochim. Biophys. Acta 1822, 361-369. doi: 10.1016/j.bbadis.2011.08.007

Reaven, G. M., Thompson, L. W., Nahum, D., and Haskins, E. (1990). Relationship between hyperglycemia and cognitive function in older NIDDM patients. Diabetes Care 13, 16-21. doi: 10.2337/diacare.13.1.16

Regenold, W. T., Thapar, R. K., Marano, C., Gavirneni, S., and Kondapavuluru, P. V. (2002). Increased prevalence of type 2 diabetes mellitus among psychiatric inpatients with bipolar I affective and schizoaffective disorders independent of psychotropic drug use. J. Affect. Disord. 70, 19-26. doi: 10.1016/S01650327(01)00456-6

Reijmer, Y. D., van den Berg, E., de Bresser, J., Kessels, R. P. C., Kappelle, L. J., Algra, A., et al. (2011). Accelerated cognitive decline in patients with type 2 diabetes: MRI correlates and risk factors. Diabetes Metab. Res. Rev. 27, 195-202. doi: $10.1002 /$ dmrr.1163

Reitz, C., Tang, M.-X., Manly, J., Mayeux, R., and Luchsinger, J. A. (2007). Hypertension and the risk of mild cognitive impairment. Arch. Neurol. 64, 1734-1740. doi: 10.1001/archneur.64.12.1734

*5,6,a, $\mathbf{\wedge}$ Restom, K., Bangen, K. J., Bondi, M. W., Perthen, J. E., and Liu, T. T. (2007). Cerebral blood flow and BOLD responses to a memory encoding task: a comparison between healthy young and elderly adults. Neuroimage 37, 430-439. doi: 10.1016/j.neuroimage.2007.05.024

${ }^{* 7,8, a}$ Rieckmann, A., Fischer, H., and Bäckman, L. (2010). Activation in striatum and medial temporal lobe during sequence learning in younger and 
older adults: relations to performance. Neuroimage 50, 1303-1312. doi: 10.1016/j.neuroimage.2010.01.015

${ }^{* 7,8, a}$ Rieckmann, A., Karlsson, S., Fischer, H., and Bäckman, L. (2011). Caudate dopamine D1 receptor density is associated with individual differences in frontoparietal connectivity during working memory. J. Neurosci. 31, 14284-14290. doi: 10.1523/JNEUROSCI.3114-11.2011

Rizzo, M. R., Marfella, R., Barbieri, M., Boccardi, V., Vestini, F., Lettieri, B., et al. (2010). Relationships between daily acute glucose fluctuations and cognitive performance among aged type 2 diabetic patients. Diabetes Care 33, 2169-2174. doi: 10.2337/dc10-0389

Roberts, R. O., Knopman, D. S., Geda, Y. E., Cha, R. H., Pankratz, V. S., Baertlein, L., et al. (2014). Association of diabetes with amnestic and nonamnestic mild cognitive impairment. Alzheimers. Dement. 10, 18-26. doi: 10.1016/j.jalz.2013.01.001

${ }^{* 5,6, a}$ Rombouts, S. A. R. B., Barkhof, F., Goekoop, R., Stam, C. J., and Scheltens, P. (2005a). Altered resting state networks in mild cognitive impairment and mild Alzheimer's disease: an fMRI study. Hum. Brain Mapp. 26, 231-239. doi: 10.1002/hbm. 20160

$* 5,6, a, \bullet$ Rombouts, S. A. R. B., Goekoop, R., Stam, C. J., Barkhof, F., and Scheltens, P. (2005b). Delayed rather than decreased BOLD response as a marker for early Alzheimer's disease. Neuroimage 26, 1078-1085. doi: 10.1016/j.neuroimage.2005.03.022

*7,10,b, Rosano, C., Venkatraman, V. K., Guralnik, J., Newman, A. B., Glynn, N. W., Launer, L., et al. (2010). Psychomotor speed and functional brain MRI 2 years after completing a physical activity treatment. J. Gerontol. A Biol. Sci. Med. Sci. 65, 639-647. doi: 10.1093/gerona/glq038

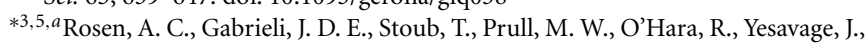
et al. (2005). Relating medial temporal lobe volume to frontal fMRI activation for memory encoding in older adults. Cortex 41, 595-602. doi: 10.1016/S00109452(08)70199-0

Ryan, C. M., and Geckle, M. O. (2000). Circumscribed cognitive dysfunction in middle-aged adults with type 2 diabetes. Diabetes Care 23, 1486-1493. doi: 10.2337/diacare.23.10.1486

${ }^{* 4, b}$ Rypma, B., Berger, J. S., Genova, H. M., Rebbechi, D., and D’Esposito, M. (2005). Dissociating age-related changes in cognitive strategy and neural efficiency using event-related fMRI. Cortex 41, 582-594. doi: 10.1016/S00109452(08)70198-9

${ }^{* 4, b}$ Rypma, B., Eldreth, D. A., and Rebbechi, D. (2007). Age-related differences in activation-performance relations in delayed-response tasks: a multiple component analysis. Cortex 43, 65-76. doi: 10.1016/S0010-9452(08)70446-5

${ }^{* 5,6, a}$ Sala-Llonch, R., Arenaza-Urquijo, E. M., Valls-Pedret, C., Vidal-Piñeiro, D., Bargall,ó, N., Junqu,é, C., et al. (2012). Dynamic functional reorganizations and relationship with working memory performance in healthy aging. Front. Hum. Neurosci. 6, 152. doi: 10.3389/fnhum.2012.00152

${ }^{* 5,6, b}$ Salami, A., Eriksson, J., and Nyberg, L. (2012). Opposing effects of aging on large-scale brain systems for memory encoding and cognitive control. J. Neurosci. 32, 10749-10757. doi: 10.1523/JNEUROSCI.0278-12.2012

$* 4, a, \bullet$ Sambataro, F., Murty, V. P., Callicott, J. H., Tan, H.-Y., Das, S., Weinberger, D. R., et al. (2010). Age-related alterations in default mode network: impact on working memory performance. Neurobiol. Aging 31, 839-852. doi: 10.1016/j.neurobiolaging.2008.05.022

${ }^{* 3,5, a}$ Schneider-Garces, N. J., Gordon, B. A., Brumback-Peltz, C. R., Shin, E., Lee, Y., Sutton, B. P., et al. (2010). Span, CRUNCH, and beyond: working memory capacity and the aging brain. J. Cogn. Neurosci. 22, 655-669. doi: 10.1162/jocn.2009.21230

${ }^{* 7,9, c}$ Schulte, T., Müller-Oehring, E. M., Chanraud, S., Rosenbloom, M. J., Pfefferbaum, A., and Sullivan, E. V. (2011). Age-related reorganization of functional networks for successful conflict resolution: a combined functional and structural MRI study. Neurobiol. Aging 32, 2075-2090. doi: 10.1016/j.neurobiolaging.2009.12.002

Scuteri, A., Tesauro, M., Appolloni, S., Preziosi, F., Brancati, A. M., and Volpe, M. (2007). Arterial stiffness as an independent predictor of longitudinal changes in cognitive function in the older individual. J. Hypertens. 25, 1035-1040. doi: 10.1097/01.hjh.0000170384.38708.b7

${ }^{* 7,8, a}$ Shafto, M. A., Stamatakis, E. A., Tam, P. P., and Tyler, L. K. (2010). Word retrieval failures in old age: the relationship between structure and function. J. Cogn. Neurosci. 22, 1530-1540. doi: 10.1162/jocn.2009.21321

Shaikh, S., and Nicholson, L. F. B. (2008). Advanced glycation end products induce in vitro cross-linking of alpha-synuclein and accelerate the process of intracellular inclusion body formation. J. Neurosci. Res. 86, 2071-2082. doi: $10.1002 /$ jnr. 21644

Shaw, J. E., Sicree, R. A., and Zimmet, P. Z. (2010). Global estimates of the prevalence of diabetes for 2010 and 2030. Diabetes Res. Clin. Pract. 87, 4-14. doi: 10.1016/j.diabres.2009.10.007

$* 5,6, b, \bullet$ Siedlecki, K. L., Habeck, C. G., Brickman, A. M., Gazes, Y., and Stern, Y. (2009). Examining the multifactorial nature of cognitive aging with covariance analysis of positron emission tomography data. J. Int. Neuropsychol. Soc. 15, 973-981. doi: 10.1017/S1355617709990592

${ }^{* 7,8, a}$ Simon, J. R., Vaidya, C. J., Howard, J. H., and Howard, D. V. (2012). The effects of aging on the neural basis of implicit associative learning in a probabilistic triplets learning task. J. Cogn. Neurosci. 24, 451-463. doi: 10.1162/jocn_a_00116

Smith, P. J., Blumenthal, J. A., Babyak, M. A., Hinderliter, A., and Sherwood, A. (2011). Association of vascular health and neurocognitive performance in overweight adults with high blood pressure. J. Clin. Exp. Neuropsychol. 33, 559-566. doi: 10.1080/13803395.2010.537648

Sokolova, I. A., Manukhina, E. B., Blinkov, S. M., Koshelev, V. B., Pinelis, V. G., and Rodionov, I. M. (1985). Rarefication of the arterioles and capillary network in the brain of rats with different forms of hypertension. Microvasc. Res. 30, 1-9. doi: 10.1016/0026-2862(85)90032-9

${ }^{* 2,5, d}$ Solbakk, A.-K., Fuhrmann Alpert, G., Furst, A. J., Hale, L. A., Oga, T., Chetty, S., et al. (2008). Altered prefrontal function with aging: insights into age-associated performance decline. Brain Res. 1232, 30-47. doi: 10.1016/j.brainres.2008.07.060

*5,6,a Solé-Padullés, C., Bartrés-Faz, D., Junqué, C., Vendrell, P., Rami, L., Clemente, I. C., et al. (2009). Brain structure and function related to cognitive reserve variables in normal aging, mild cognitive impairment and Alzheimer's disease. Neurobiol. Aging 30, 1114-1124. doi: 10.1016/j.neurobiolaging.2007.10.008

$* 5,6, d, \mathbf{\square}$ Spaniol, J., and Grady, C. (2012). Aging and the neural correlates of source memory: over-recruitment and functional reorganization. Neurobiol. Aging 33, 425.e3-18. doi: 10.1016/j.neurobiolaging.2010.10.005

${ }^{* 6,7, a}$ Sperling, R. A., Bates, J. F., Chua, E. F., Cocchiarella, A. J., Rentz, D. M., Rosen, B. R., et al. (2003). fMRI studies of associative encoding in young and elderly controls and mild Alzheimer's disease. J. Neurol. Neurosurg. Psychiatr. 74, 44-50. doi: 10.1136/jnnp.74.1.44

*10,12,b Stebbins, G. T., Carrillo, M. C., Dorfman, J., Dirksen, C., Desmond, J. E., Turner, D. A., et al. (2002). Aging effects on memory encoding in the frontal lobes. Psychol. Aging 17, 44-55. doi: 10.1037/0882-7974.17.1.44

Steen, E., Terry, B. M., Rivera, E. J., Cannon, J. L., Neely, T. R., Tavares, R., et al. (2005). Impaired insulin and insulin-like growth factor expression and signaling mechanisms in Alzheimer's disease-is this type 3 diabetes? J. Alzheimers Dis. 7, $63-80$.

${ }^{* 5,6, b}$ Steffener, J., Brickman, A. M., Rakitin, B. C., Gazes, Y., and Stern, Y. (2009). The impact of age-related changes on working memory functional activity. Brain Imaging Behav. 3, 142-153. doi: 10.1007/s11682-008-9056-X

*5,6,a Stern, Y., Habeck, C., Moeller, J., Scarmeas, N., Anderson, K. E., Hilton, H. J., et al. (2005). Brain networks associated with cognitive reserve in healthy young and old adults. Cereb. Cortex 15, 394-402. doi: 10.1093/cercor/bhh142

${ }^{* 4, a}$ Stern, Y., Rakitin, B. C., Habeck, C., Gazes, Y., Steffener, J., Kumar, A., et al. (2012). Task difficulty modulates young-old differences in network expression. Brain Res. 1435, 130-145. doi: 10.1016/j.brainres.2011.11.061

*7,8,a Stern, Y., Zarahn, E., Habeck, C., Holtzer, R., Rakitin, B. C., Kumar, A., et al. (2008). A common neural network for cognitive reserve in verbal and object working memory in young but not old. Cereb. Cortex 18, 959-967. doi: 10.1093/cercor/bhm134

${ }^{* 4, a}$ Stevens, W. D., Hasher, L., Chiew, K. S., and Grady, C. L. (2008). A neural mechanism underlying memory failure in older adults. J. Neurosci. 28, 12820-12824. doi: 10.1523/JNEUROSCI.2622-08.2008

${ }^{* 7,9, a}$ St Jacques, P. L., Rubin, D. C., and Cabeza, R. (2012). Age-related effects on the neural correlates of autobiographical memory retrieval. Neurobiol. Aging 33 , 1298-1310. doi: 10.1016/j.neurobiolaging.2010.11.007

*5,6,a Thiyagesh, S. N., Farrow, T. F. D., Parks, R. W., Accosta-Mesa, H., Young, C., Wilkinson, I. D., et al. (2009). The neural basis of visuospatial perception in Alzheimer's disease and healthy elderly comparison subjects: an fMRI study. Psychiatry Res. 172, 109-116. doi: 10.1016/j.pscychresns.2008.11.002

${ }^{* 7,8, a}$ Thomsen, T., Specht, K., Rimol, L. M., Hammar, A., Nyttingnes, J., Ersland, L., et al. (2004). Brain localization of attentional control in different age groups by combining functional and structural MRI. Neuroimage 22, 912-919. doi: 10.1016/j.neuroimage.2004.02.015 
*5,9,a Townsend, J., Adamo, M., and Haist, F. (2006). Changing channels: an fMRI study of aging and cross-modal attention shifts. Neuroimage 31, 1682-1692. doi: 10.1016/j.neuroimage.2006.01.045

Triantafyllidi, H., Arvaniti, C., Lekakis, J., Ikonomidis, I., Siafakas, N., Tzortzis, S., et al. (2009). Cognitive impairment is related to increased arterial stiffness and microvascular damage in patients with never-treated essential hypertension. Am. J. Hypertens. 22, 525-530. doi: 10.1038/ajh.2009.35

${ }^{* 5,6, b}$ Trivedi, M. A., Murphy, C. M., Goetz, C., Shah, R. C., Gabrieli, J. D. E., Whitfield-Gabrieli, S., et al. (2008a). fMRI activation changes during successful episodic memory encoding and recognition in amnestic mild cognitive impairment relative to cognitively healthy older adults. Dement. Geriatr. Cogn. Disord. 26, 123-137. doi: 10.1159/000148190

*1,6,a Trivedi, M. A., Schmitz, T. W., Ries, M. L., Hess, T. M., Fitzgerald, M. E., Atwood, C. S., et al. (2008b). fMRI activation during episodic encoding and metacognitive appraisal across the lifespan: risk factors for Alzheimer's disease. Neuropsychologia 46, 1667-1678. doi: 10.1016/j.neuropsychologia.2007.11.035

${ }^{* 4, b}$ Trivedi, M. A., Stoub, T. R., Murphy, C. M., George, S., deToledo-Morrell, L., Shah, R. C., et al. (2011). Entorhinal cortex volume is associated with episodic memory related brain activation in normal aging and amnesic mild cognitive impairment. Brain Imaging Behav. 5, 126-136. doi: 10.1007/s11682-011-9117-4

*5,6,a Tsukiura, T., Sekiguchi, A., Yomogida, Y., Nakagawa, S., Shigemune, Y., Kambara, T., et al. (2011). Effects of aging on hippocampal and anterior temporal activations during successful retrieval of memory for face-name associations. J. Cogn. Neurosci. 23, 200-213. doi: 10.1162/jocn.2010.21476

Tuligenga, R. H., Dugravot, A., Tabák, A. G., Elbaz, A., Brunner, E. J., Kivimäki, M., et al. (2014). Midlife type 2 diabetes and poor glycaemic control as risk factors for cognitive decline in early old age: a post-hoc analysis of the Whitehall II cohort study. Lancet Diabetes Endocrinol. 2, 228-235. doi: 10.1016/S22138587(13)70192-X.

*7,8,a Tyler, L. K., Shafto, M. A., Randall, B., Wright, P., Marslen-Wilson, W. D., and Stamatakis, E. A. (2010). Preserving syntactic processing across the adult life span: the modulation of the frontotemporal language system in the context of age-related atrophy. Cereb. Cortex 20, 352-364. doi: 10.1093/cercor/bhp105

${ }^{* 7,8, a}$ Vallesi, A., McIntosh, A. R., and Stuss, D. T. (2009). Temporal preparation in aging: a functional MRI study. Neuropsychologia 47, 2876-2881. doi: 10.1016/j.neuropsychologia.2009.06.013

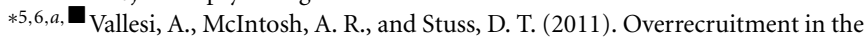
aging brain as a function of task demands: evidence for a compensatory view. J. Cogn. Neurosci. 23, 801-815. doi: 10.1162/jocn.2010.21490

van den Berg, E., Reijmer, Y. D., de Bresser, J., Kessels, R. P. C., Kappelle, L. J., and Biessels, G. J. (2010). A 4 year follow-up study of cognitive functioning in patients with type 2 diabetes mellitus. Diabetologia 53, 58-65. doi: 10.1007/s00125-009-1571-9

${ }^{* 4, a}$ Vandenbroucke, M. W. G., Goekoop, R., Duschek, E. J. J., Netelenbos, J. C., Kuijer, J. P. A., Barkhof, F., et al. (2004). Interindividual differences of medial temporal lobe activation during encoding in an elderly population studied by fMRI. Neuroimage 21, 173-180. doi: 10.1016/j.neuroimage.2003.09.043

${ }^{* 4, c}$ van der Veen, F. M., Nijhuis, F. A. P., Tisserand, D. J., Backes, W. H., and Jolles, J. (2006). Effects of aging on recognition of intentionally and incidentally stored words: an fMRI study. Neuropsychologia 44, 2477-2486. doi: 10.1016/j.neuropsychologia.2006.04.023

van Elderen, S. G. C., de Roos, A., de Craen, A. J. M., Westendorp, R. G. J., Blauw, G. J., Jukema, J. W., et al. (2010). Progression of brain atrophy and cognitive decline in diabetes mellitus: a 3-year follow-up. Neurology 75, 997-1002. doi: 10.1212/WNL.0b013e3181f25f06

$* 7,8, a$ van Impe, A., Coxon, J. P., Goble, D. J., Wenderoth, N., and Swinnen, S. P. (2011). Age-related changes in brain activation underlying single- and dual-task performance: visuomanual drawing and mental arithmetic. Neuropsychologia 49, 2400-2409. doi: 10.1016/j.neuropsychologia.2011.04.016

$* 5,6, a, \bullet$ Velanova, K., Lustig, C., Jacoby, L. L., and Buckner, R. L. (2007). Evidence for frontally mediated controlled processing differences in older adults. Cereb. Cortex 17, 1033-1046. doi: 10.1093/cercor/bhl013

$* 7,8, a, *$ Venkatraman, V. K., Aizenstein, H., Guralnik, J., Newman, A. B., Glynn, N. W., Taylor, C., et al. (2010). Executive control function, brain activation and white matter hyperintensities in older adults. Neuroimage 49, 3436-3442. doi: 10.1016/j.neuroimage.2009.11.019

Virta, J. J., Heikkilä, K., Perola, M., Koskenvuo, M., Räihä, I., Rinne, J. O., et al. (2013). Midlife cardiovascular risk factors and late cognitive impairment. Eur. J. Epidemiol. 28, 405-416. doi: 10.1007/s10654-013-9794-y
${ }^{* 7,8, a}$ Voelcker-Rehage, C., Godde, B., and Staudinger, U. M. (2010). Physical and motor fitness are both related to cognition in old age. Eur. J. Neurosci. 31, 167-176. doi: 10.1111/j.1460-9568.2009.07014.x

${ }^{* 7,8, a}$ Waiter, G. D., Fox, H. C., Murray, A. D., Starr, J. M., Staff, R. T., Bourne, V. J., et al. (2008). Is retaining the youthful functional anatomy underlying speed of information processing a signature of successful cognitive ageing? An eventrelated fMRI study of inspection time performance. Neuroimage 41, 581-595. doi: 10.1016/j.neuroimage.2008.02.045

Waldstein, S. R., Carrington, S., Thayer, J. F., Najjar, S. S., Scuteri, A., and Zonderman, A. B. (2008). Pulse pressure and pulse wave velocity are related to cognitive decline in the Baltimore Longitudinal Study of Aging. Hypertension 51, 99-104. doi: 10.1161/HYPERTENSIONAHA.107.093674

${ }^{* 5,6, a}$ Wang, L., Laviolette, P., O’Keefe, K., Putcha, D., Bakkour, A., Van Dijk, K. R. A., et al. (2010a). Intrinsic connectivity between the hippocampus and posteromedial cortex predicts memory performance in cognitively intact older individuals. Neuroimage 51, 910-917. doi: 10.1016/j.neuroimage.2010.02.046

*7,9,a Wang, L., Li, Y., Metzak, P., He, Y., and Woodward, T. S. (2010b). Agerelated changes in topological patterns of large-scale brain functional networks during memory encoding and recognition. Neuroimage 50, 862-872. doi: 10.1016/j.neuroimage.2010.01.044

${ }^{* 7,9, a}$ Wang, T. H., Kruggel, F., and Rugg, M. D. (2009). Effects of advanced aging on the neural correlates of successful recognition memory. Neuropsychologia 47, 1352-1361. doi: 10.1016/j.neuropsychologia.2009.01.030

Weis, S., Leube, D., Erb, M., Heun, R., Grodd, W., and Kircher, T. (2011). Functional neuroanatomy of sustained memory encoding performance in healthy aging and in Alzheimer's disease. Int. J. Neurosci. 121, 384-392. doi: 10.3109/00207454.2011.565892

White, W. B., Wolfson, L., Wakefield, D. B., Hall, C. B., Campbell, P., Moscufo, N., et al. (2011). Average daily blood pressure, not office blood pressure, is associated with progression of cerebrovascular disease and cognitive decline in older people. Circulation 124, 2312-2319. doi: 10.1161/CIRCULATIONAHA.111.037036

Whitehead, B. P., Dixon, R. A., Hultsch, D. F., and MacDonald, S. W. S. (2011). Are neurocognitive speed and inconsistency similarly affected in type 2 diabetes? J. Clin. Exp. Neuropsychol. 33, 647-657. doi: 10.1080/13803395.2010.547845

$* 7,9, a, \mathbf{x}$ Wierenga, C. E., Benjamin, M., Gopinath, K., Perlstein, W. M., Leonard, C. M., Rothi, L. J. G., et al. (2008). Age-related changes in word retrieval: role of bilateral frontal and subcortical networks. Neurobiol. Aging 29, 436-451. doi: 10.1016/j.neurobiolaging.2006.10.024

$* 7,9, b, \mathbf{\square}, \square$ Wierenga, C. E., Stricker, N. H., McCauley, A., Simmons, A., Jak, A. J., Chang, Y.-L., et al. (2010). Increased functional brain response during word retrieval in cognitively intact older adults at genetic risk for Alzheimer's disease. Neuroimage 51, 1222-1233. doi: 10.1016/j.neuroimage.2010.03.021

${ }^{* 5,6, a}$ Wood, G., Ischebeck, A., Koppelstaetter, F., Gotwald, T., and Kaufmann, L. (2009). Developmental trajectories of magnitude processing and interference control: an FMRI study. Cereb. Cortex 19, 2755-2765. doi: 10.1093/cercor/bhp056

${ }^{* 7,8, a}$ Woodard, J. L., Seidenberg, M., Nielson, K. A., Antuono, P., Guidotti, L., Durgerian, S., et al. (2009). Semantic memory activation in amnestic mild cognitive impairment. Brain 132, 2068-2078. doi: 10.1093/brain/awp157

${ }^{* 5,6, a}$ Woodard, J. L., Seidenberg, M., Nielson, K. A., Miller, S. K., Franczak, M., Antuono, P., et al. (2007). Temporally graded activation of neocortical regions in response to memories of different ages. J. Cogn. Neurosci. 19, 1113-1124. doi: 10.1162/jocn.2007.19.7.1113

${ }^{* 5,6, c}$ Woodard, J. L., Seidenberg, M., Nielson, K. A., Smith, J. C., Antuono, P., Durgerian, S., et al. (2010). Prediction of cognitive decline in healthy older adults using fMRI. J. Alzheimers Dis. 21, 871-885. doi: 10.3233/JAD-2010091693

*5,6,c Woodard, J. L., Sugarman, M. A., Nielson, K. A., Smith, J. C., Seidenberg, M., Durgerian, S., et al. (2012). Lifestyle and genetic contributions to cognitive decline and hippocampal structure and function in healthy aging. Curr. Alzheimer Res. 9, 436-446. doi: 10.2174/156720512800492477

$* 5,6, a, \bullet$ Wu, J.-T., Wu, H.-Z., Yan, C.-G., Chen, W.-X., Zhang, H.-Y., He, Y., et al. (2011). Aging-related changes in the default mode network and its anticorrelated networks: a resting-state fMRI study. Neurosci. Lett. 504, 62-67. doi: 10.1016/j.neulet.2011.08.059

Xu, W., Caracciolo, B., Wang, H.-X., Winblad, B., Bäckman, L., Qiu, C., et al. (2010). Accelerated progression from mild cognitive impairment to dementia in people with diabetes. Diabetes 59, 2928-2935. doi: 10.2337/db10-0539 
Yaffe, K., Blackwell, T., Kanaya, A. M., Davidowitz, N., Barrett-Connor, E., and Krueger, K. (2004). Diabetes, impaired fasting glucose, and development of cognitive impairment in older women. Neurology 63, 658-663. doi: 10.1212/01.WNL.0000134666.64593.BA

Yaffe, K., Lindquist, K., Schwartz, A. V., Vitartas, C., Vittinghoff, E., Satterfield, S., et al. (2011). Advanced glycation end product level, diabetes, and accelerated cognitive aging. Neurology 77, 1351-1356. doi: 10.1212/WNL.0b013e3182315a56

Yakushiji, Y., Noguchi, T., Hara, M., Nishihara, M., Eriguchi, M., Nanri, Y., et al. (2012). Distributional impact of brain microbleeds on global cognitive function in adults without neurological disorder. Stroke 43, 1800-1805. doi: 10.1161/STROKEAHA.111.647065

Yan, S. F., Ramasamy, R., and Schmidt, A. M. (2008). Mechanisms of disease: advanced glycation end-products and their receptor in inflammation and diabetes complications. Nat. Clin. Pract. Endocrinol. Metab. 4, 285-293. doi: 10.1038/ncpendmet0786

Yeung, S. E., Fischer, A. L., and Dixon, R. A. (2009). Exploring effects of type 2 diabetes on cognitive functioning in older adults. Neuropsychology 23, 1-9. doi: $10.1037 / \mathrm{a} 0013849$

${ }^{* 5,6, c}$ Ystad, M., Eichele, T., Lundervold, A. J., and Lundervold, A. (2010). Subcortical functional connectivity and verbal episodic memory in healthy elderly — a resting state fMRI study. Neuroimage 52, 379-388. doi: 10.1016/j.neuroimage.2010.03.062

*5,6,c Ystad, M., Hodneland, E., Adolfsdottir, S., Haász, J., Lundervold, A. J., Eichele, T., et al. (2011). Cortico-striatal connectivity and cognition in normal aging: a combined DTI and resting state fMRI study. Neuroimage 55, 24-31. doi: 10.1016/j.neuroimage.2010.11.016

Zhong, Y., Miao, Y., Jia, W. P., Yan, H., Wang, B. Y., and Jin, J. (2012a). Hyperinsulinemia, insulin resistance and cognitive decline in older cohort. Biomed. Environ. Sci. 25, 8-14. doi: 10.3967/0895-3988.2012.01.002
Zhong, Y., Zhang, X. Y., Miao, Y., Zhu, J. H., Yan, H., Wang, B. Y., et al. (2012b). The relationship between glucose excursion and cognitive function in aged type 2 diabetes patients. Biomed. Environ. Sci. 25, 1-7. doi: 10.3967/08953988.2012.01.001

Zhou, H., Lu, W., Shi, Y., Bai, F., Chang, J., Yuan, Y., et al. (2010). Impairments in cognition and resting-state connectivity of the hippocampus in elderly subjects with type 2 diabetes. Neurosci. Lett. 473, 5-10. doi: 10.1016/j.neulet.2009. 12.057

$* 7,8, a, \bullet$ Zhu, D. C., Zacks, R. T., and Slade, J. M. (2010). Brain activation during interference resolution in young and older adults: an fMRI study. Neuroimage 50, 810-817. doi: 10.1016/j.neuroimage.2009. 12.087

Conflict of Interest Statement: The authors declare that the research was conducted in the absence of any commercial or financial relationships that could be construed as a potential conflict of interest.

Received: 25 January 2014; accepted: 17 June 2014; published online: 08 July 2014. Citation: Meusel L-AC, Kansal N, Tchistiakova E, Yuen W, MacIntosh BJ, Greenwood CE and Anderson ND (2014) A systematic review of type 2 diabetes mellitus and hypertension in imaging studies of cognitive aging: time to establish new norms. Front. Aging Neurosci. 6:148. doi: 10.3389/fnagi.2014.00148

This article was submitted to the journal Frontiers in Aging Neuroscience.

Copyright (c) 2014 Meusel, Kansal, Tchistiakova, Yuen, MacIntosh, Greenwood and Anderson. This is an open-access article distributed under the terms of the Creative Commons Attribution License (CC BY). The use, distribution or reproduction in other forums is permitted, provided the original author(s) or licensor are credited and that the original publication in this journal is cited, in accordance with accepted academic practice. No use, distribution or reproduction is permitted which does not comply with these terms. 